Prepared in cooperation with the Puerto Rico Department of Natural and Environmental Resources

\title{
The Effects of Forest Cover on Base Flow of Streams in the Mountainous Interior of Puerto Rico, 2010
}

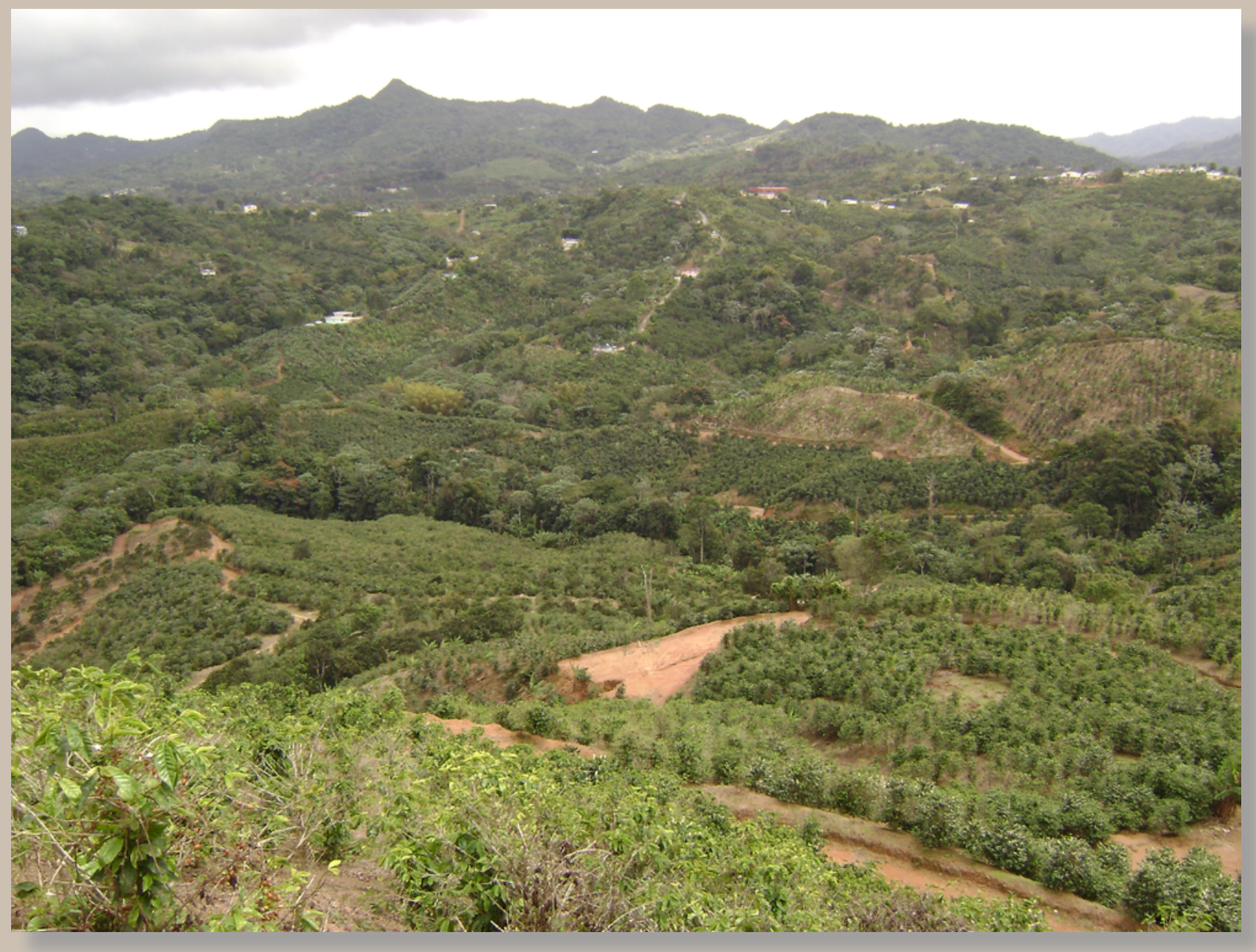

Scientific Investigations Report 2016-5142 
Cover. Looking west toward to a plantation of sun and shade coffee in the municipality of Adjuntas, Puerto Rico, March 12, 2009. Photograph by Jesús Rodríguez-Martínez. 


\section{The Effects of Forest Cover on Base Flow of Streams in the Mountainous Interior of Puerto Rico, 2010}

By Jesús Rodríguez-Martínez and Marilyn Santiago

Prepared in cooperation with the Puerto Rico Department of Natural and Environmental Resources

Scientific Investigations Report 2016-5142 


\title{
U.S. Department of the Interior SALLY JEWELL, Secretary
}

\section{U.S. Geological Survey William H. Werkheiser, Acting Director}

\author{
U.S. Geological Survey, Reston, Virginia: 2017
}

For more information on the USGS - the Federal source for science about the Earth, its natural and living resources, natural hazards, and the environment—visit http://www.usgs.gov or call 1-888-ASK-USGS.

For an overview of USGS information products, including maps, imagery, and publications, visit http://www.usgs.gov/pubprod/.

Any use of trade, firm, or product names is for descriptive purposes only and does not imply endorsement by the U.S. Government.

Although this information product, for the most part, is in the public domain, it also may contain copyrighted materials as noted in the text. Permission to reproduce copyrighted items must be secured from the copyright owner.

Suggested citation:

Rodríguez-Martínez, Jesús, and Santiago, Marilyn, 2017, The effects of forest cover on base flow of streams in the mountainous interior of Puerto Rico, 2010: U.S. Geological Survey Scientific Investigations Report 2016-5142, 19 p, https://doi.org/10.3133/sir20165142. 


\section{Acknowledgments}

The authors acknowledge Mr. Edelmiro Torres, who allowed the installation of instruments for data collection on his farm in the municipality of Adjuntas, and who provided assistance during times of harsh weather. The authors also acknowledge the contributions of the following employees of the U.S. Geological Survey Caribbean-Florida Water Science Center: Fernando Gómez-Gómez (retired) helped conceptualize the study proposal and assisted in the initial stages of field reconnaissance. Sigfredo Torres-González assisted in estimating the evapotranspiration of the study area. Elliot Sosa, Heriberto Torres-Sierra (retired), Manuel Rosario, and David Hernández helped install monitoring instruments, and collect and process data for the study. 



\section{Contents}

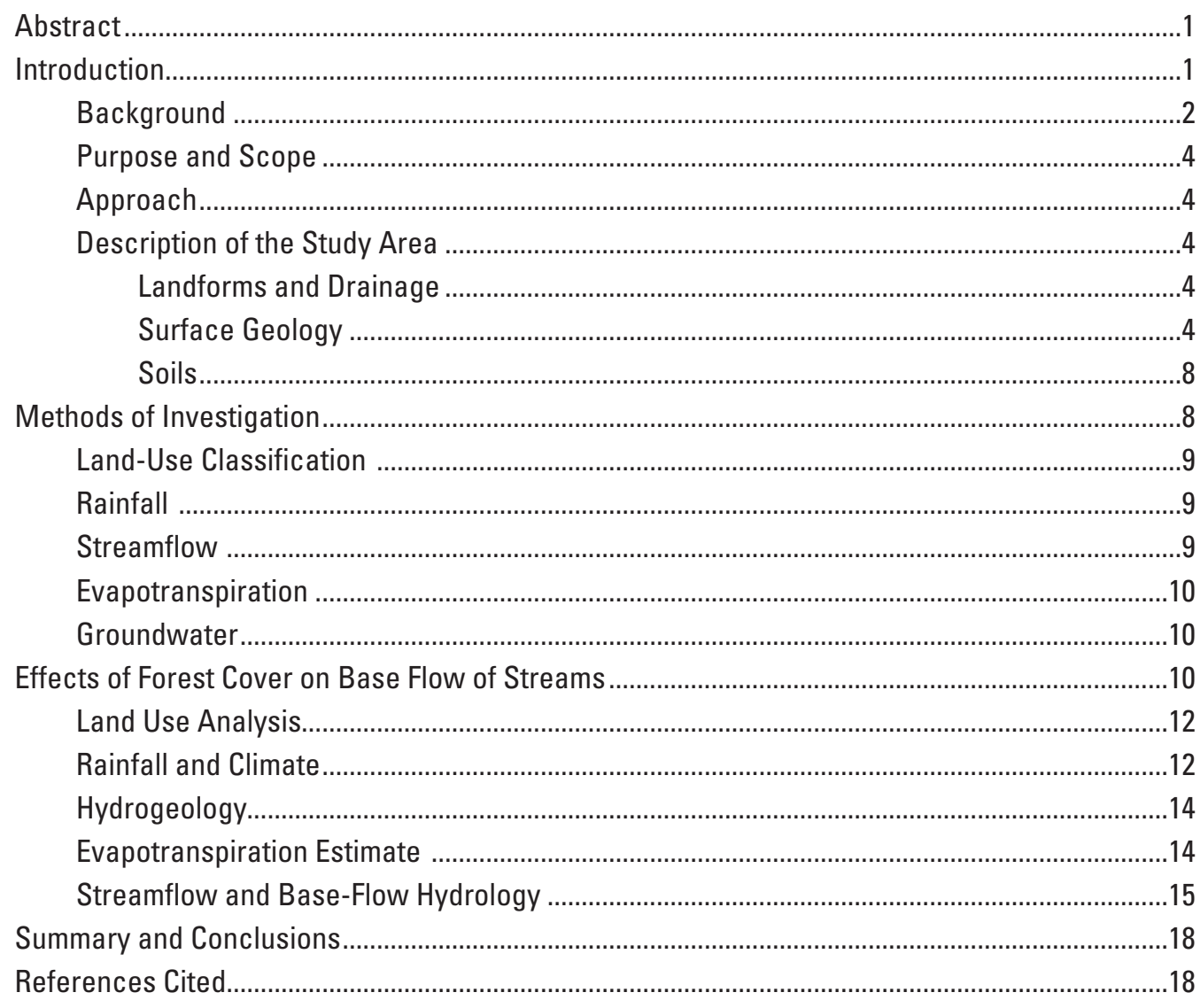

\section{Figures}

1. Map of Puerto Rico showing the location of the study area in the Cordillera

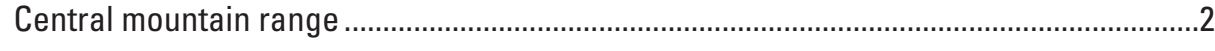

2. Aerial photo showing paired basins used in the study …..............................................

3. Topographic map showing subbasins of Río Guaónica and Río Tanamá with data

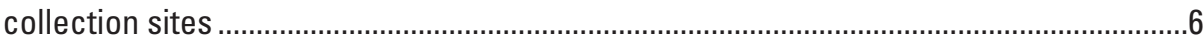

4. Topographic map showing subbasins of Tributary 1 and 2 in the Rio Coabey Basin with data collection sites .............................................................................................

5. Map showing surface geology of the two sets of paired basins in the study area ..........8

6. Map showing the location of USGS streamflow gaging stations in study area ..............11

7. Maps showing the spatial distribution of the main land-use type classification in the two paired basins.

8. Graphs showing monthly rainfall during 2010 at the La Mira, and Barrio Roncador rainfall stations

9. Lithologic logs showing main shallow lithologies and screened intervals at the test holes and piezometers in the study area

10. Hydrographs showing base flow computed for Rio Guaónica, Rio Tanamá, and Rio Coabey Tributaries 1 and 2 


\section{Tables}

1. Characteristics of study area basins................................................................................

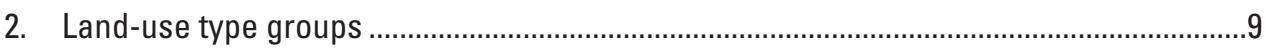

3. Data-collection sites, type, and coordinates ......................................................................10

4. Areal extent of basins and percentage of land-use type classification within each of the paired basins

5. Water-level data collected at selected sites in the study area ......................................15

6. Range in normalized daily base flow at the paired basins for calendar year 2010 .........17

7. Mean annual streamflow and base flow at the two paired basins in calendar year 2010

8. Normalized base flow and low flow in the two paired basins during calendar year 2010

\section{Conversion Factors}

Inch/Pound to International System of Units

\begin{tabular}{|c|c|c|}
\hline Multiply & By & To obtain \\
\hline \multicolumn{3}{|c|}{ Length } \\
\hline inch (in.) & 2.54 & centimeter $(\mathrm{cm})$ \\
\hline inch (in.) & 25.4 & millimeter $(\mathrm{mm})$ \\
\hline foot (ft) & 0.3048 & meter $(\mathrm{m})$ \\
\hline square mile $\left(\mathrm{mi}^{2}\right)$ & 2.590 & square kilometer $\left(\mathrm{km}^{2}\right)$ \\
\hline \multicolumn{3}{|c|}{ Flow rate } \\
\hline cubic foot per second $\left(\mathrm{ft}^{3} / \mathrm{s}\right)$ & 0.02832 & cubic meter per second $\left(\mathrm{m}^{3} / \mathrm{s}\right)$ \\
\hline $\begin{array}{l}\text { cubic foot per second per square mile } \\
\qquad\left(\left[\mathrm{ft}^{3} / \mathrm{s}\right] / \mathrm{mi}^{2}\right)\end{array}$ & 0.01093 & $\begin{array}{l}\text { cubic meter per second per square kilometer } \\
\qquad\left(\left[\mathrm{m}^{3} / \mathrm{s}\right] / \mathrm{km}^{2}\right)\end{array}$ \\
\hline inch per year (in/yr) & 25.4 & millimeter per year (mm/yr) \\
\hline mile per hour $(\mathrm{mi} / \mathrm{h})$ & 1.609 & kilometer per hour $(\mathrm{km} / \mathrm{h})$ \\
\hline \multicolumn{3}{|c|}{ Pressure } \\
\hline inch of mercury at $60^{\circ} \mathrm{F}$ (in $\mathrm{Hg}$ ) & 2.54 & millimeter of mercury $(\mathrm{mm} \mathrm{Hg})$ \\
\hline \multicolumn{3}{|c|}{ Solar radiation } \\
\hline watt per square meter $\left(\mathrm{W} / \mathrm{m}^{2}\right)$ & 10.76 & watt per square foot $\left(\mathrm{W} / \mathrm{ft}^{2}\right)$ \\
\hline
\end{tabular}

\section{Datums}

Vertical coordinate information is referenced to local mean sea level.

Horizontal coordinate information is referenced to the North American Datum of 1927 (NAD 27).

Altitude, as used in this report, refers to distance above the vertical datum. 


\section{Abbreviations}

$\begin{array}{ll}\text { blsd } & \text { below land surface datum } \\ \text { ET } & \text { evapotranspiration } \\ \text { K } & \text { hydraulic conductivity } \\ \text { municipio } & \text { municipality } \\ \text { PRDNER } & \text { Puerto Rico Department of Natural and Environmental Resources } \\ \text { PRDOA } & \text { Puerto Rico Department of Agriculture } \\ \text { PVC } & \text { polyvinyl chloride } \\ \text { USFS } & \text { U.S. Forest Service } \\ \text { USGS } & \text { U.S. Geological Survey } \\ \text { WHAT } & \text { Web Based Hydrograph Analysis Tool }\end{array}$





\title{
The Effects of Forest Cover on Base Flow of Streams in the Mountainous Interior of Puerto Rico, 2010
}

\author{
By Jesús Rodríguez-Martínez and Marilyn Santiago
}

\section{Abstract}

The U.S. Geological Survey, in cooperation with the Puerto Rico Department of Natural and Environmental Resources, completed a study to determine whether a relation exists between the extent of forest cover and the magnitude of base flow at two sets of paired drainage basins in the highlands of the municipalities of Adjuntas and Utuado within the mountainous interior of Puerto Rico. One set of paired basins includes the Río Guaónica and Río Tanamá, both tributaries of the Río Grande de Arecibo. The other set includes two smaller basins in the drainage basin of the Río Coabey, which is a tributary of the Río Tanamá. The paired basins in each set have similar rainfall patterns, geologic substrate, and aspect; the principal difference identified in the study is the extent of forest cover and related land uses such as the cultivation of shade and sun coffee. Data describing the hydrology, hydrogeology, and streamflow were used in the analysis. The principal objective of the study was to compare base flow per unit area among basins having different areal extents of forest cover and land uses such as shade coffee and sun coffee cultivation.

Within the mountainous interior of Puerto Rico, a substantial amount of the annual rainfall (45 to 39 percent in the Rio Guaónica and Rio Tanamá, respectively) can migrate to the subsurface and later emerge as base flow in streams. The magnitude of base flow within the two sets of paired basins varies seasonally. Minimum base flows occur during the annual dry season (generally from January to March), and maximum base flows occur during the wet season (generally from August to October). During the dry season or periods of below-normal rainfall, base flow is either the primary or the sole component of streamflow. Daily mean base flow ranged from 3.2 to 20.5 cubic feet per second $\left(\mathrm{ft}^{3} / \mathrm{s}\right)$ at the Rio Guaónica Basin, and from 4.2 to $23.0 \mathrm{ft}^{3} / \mathrm{s}$ at the Rio Tanamá Basin. The daily mean base flows during 2010 ranged from 0.28 to $0.98 \mathrm{ft}^{3} / \mathrm{s}$ at Tributary 1 and from 0.22 to $0.58 \mathrm{ft}^{3} / \mathrm{s}$ at Tributary 2 of the Rio Coabey. The normalized daily base flow at the Río Guaónica and Río Tanamá Basin during 2010 ranged from 1.3 to 8.1 cubic feet per second per square mile $\left(\mathrm{ft}^{3} / \mathrm{s}\right) / \mathrm{mi}^{2}$ and from 1.1 to $6.1\left(\mathrm{ft}^{3} / \mathrm{s}\right) / \mathrm{mi}^{2}$, respectively. The normalized daily base flow for the basins of Tributary 1 and Tributary 2 of Río Coabey during 2010 ranged from 1.0 to $3.6\left(\mathrm{ft}^{3} / \mathrm{s}\right) / \mathrm{mi}^{2}$ and from 1.5 to $3.9\left(\mathrm{ft}^{3} / \mathrm{s}\right) / \mathrm{mi}^{2}$, respectively.
The normalized mean annual base flow is similar within the larger paired basins of Río Tanamá $\left(2.74\left[\mathrm{ft}^{3} / \mathrm{s}\right] / \mathrm{mi}^{2}\right)$ and Río Guaónica $\left(3.15\left[\mathrm{ft}^{3} / \mathrm{s}\right] / \mathrm{mi}^{2}\right)$. The mean annual base flow per unit area for both of these basins is about 79 percent of the mean annual streamflow. In the large paired basins, the proportion of Type I land use (forest patches, shade and mixed shade/sun coffee with associated cash crops) is substantially higher in Rio Guaónica Basin (81 percent) than in the Rio Tanamá Basin (59 percent), and the base flow per unit area is also higher. In the small paired basins of Rio Coabey, the proportion of Type I land use is much higher at Tributary 1 (52 percent) than at Tributary 2 (15 percent), but, in contrast to the large basins, the mean annual base flow per unit area is lower (2.22 and $2.62\left[\mathrm{ft}^{3} / \mathrm{s}\right] / \mathrm{mi}^{2}$, respectively). There is no consistent relation between land use and normalized base flow between the two sets of paired basins in the study.

\section{Introduction}

The relation between streamflow and forest cover is complex, because streamflow is affected by vegetative cover, rainfall, land-surface slope, geology, and other factors. Streamflow is composed of direct runoff and base flow. Base flow is defined herein as the groundwater contribution to streamflow and consists of groundwater discharge from a drainage basin (basin, hereafter). Base flow excludes transient phenomena such as return flow and subsurface flow that occurs during or immediately after rainfall and overland runoff are generated (Hornberger and others, 1998). Return flow is caused by infiltrated rainfall that reaches the water table and reappears at the ground surface before discharging into the stream. Subsurface stormflow is the lateral flow of infiltrated rainfall caused by the saturation of a permeable soil horizon.

The low-flow component of base flow is defined herein as the streamflow that is exceeded 95 percent of the time during the one-year study period. The low flow occurs during long dry periods or periods of scarce rainfall when the water table is abnormally low. This low flow is commonly referred to as the lowest dry weather streamflow (Robinson and others, 2003). Base flow constitutes the sole or primary source of streamflow during the annual dry season when rainfall is insufficient to 
generate substantive runoff. The annual dry season in Puerto Rico typically extends from January through March, and during this period, base flow is the primary or only watersupply source available from streams for human consumption. In addition, base flow maintains the biotic integrity of a stream and its capacity to assimilate organic-waste discharges.

Results of previous studies conducted by the U.S. Geological Survey (USGS) to assess the potential water-resources development of several municipalities in Puerto Rico indicate that a direct relation may exist between high base flows and the presence of a well-developed (mature) forest cover in the highlands of the mountainous interior (fig. 1). These mountainous areas have high average annual rates of rainfall, generally exceeding 70 inches (in.). High base flows have been documented in streams within mature forested areas at altitudes between 1,000 and 1,500 feet ( $\mathrm{ft}$ ) in the headwaters of the Río Turabo at Caguas, in north-central Puerto Rico (Gómez-Gómez and others, 2001), and streams within the upland areas of Mayagüez and Ponce (RodríguezMartínez and others, 2003, 2005). Base flows have been estimated to range from 1.0 to 1.22 cubic feet per second per square mile $\left(\left[\mathrm{ft}^{3} / \mathrm{s}\right] / \mathrm{mi}^{2}\right)$ in the most upstream parts of the Río Turabo drainage basin; 0.2 to $1.1\left(\mathrm{ft}^{3} / \mathrm{s}\right) / \mathrm{mi}^{2}$ at Mayaguez; and 0.5 to $1.3\left(\mathrm{ft}^{3} / \mathrm{s}\right) / \mathrm{mi}^{2}$ at Ponce. At these three areas, mean annual rainfall typically ranges from 70 to 90 in. Base-flow rates have also been studied in basins within the municipios of Comerío and Carolina at similar altitudes but with annual rainfall averaging near 70 in. (Rodríguez-Martínez and others, 2001, 2002). The forest cover is fragmented (discontinuous) in the municipios of Comerío and Carolina, unlike the more dense forest cover in the highlands of the municipios of Caguas, Ponce, and Mayagüez. The deforestation in the municipio of Comerío was probably the result of past agricultural practices, particularly the intense cultivation of tobacco on predominantly steep slopes in the area, according to local sources and historical agricultural records. In the highlands of Carolina, agricultural practices may have been influential in the past, but urban development currently appears to be the main cause of deforestation (Rodríguez-Martínez and others, 2002).

This report describes a study completed by the USGS, in cooperation with the Puerto Rico Department of Natural and Environmental Resources (PRDNER), to determine whether a relation exists between the spatial extent of forest cover and base flow within the mountainous highlands of Puerto Rico, and if that relation could provide information to improve resource management in these areas. The results of this study could provide useful information to the PRDNER, the Puerto Rico Department of Agriculture (PRDOA) and other State and Federal agencies about the sustainability of land use in the mountainous interior of Puerto Rico. Minimizing the loss of forest cover in the mountainous interior could help preserve the hydrologic, ecological, and societal functions of streams. Ideally, environmentally sustainable land uses can be reconciled with the goal of enhancing the socioeconomic development of the mountainous interior region of Puerto Rico.

\section{Background}

Studies concerning the effects of land-cover changes on the magnitude of peak stream runoff in tropical mountainous settings are numerous (Bruijnzeel, 1990); however, studies relating land-use changes and the magnitude of base flow in tropical mountainous settings are rare. The relation between

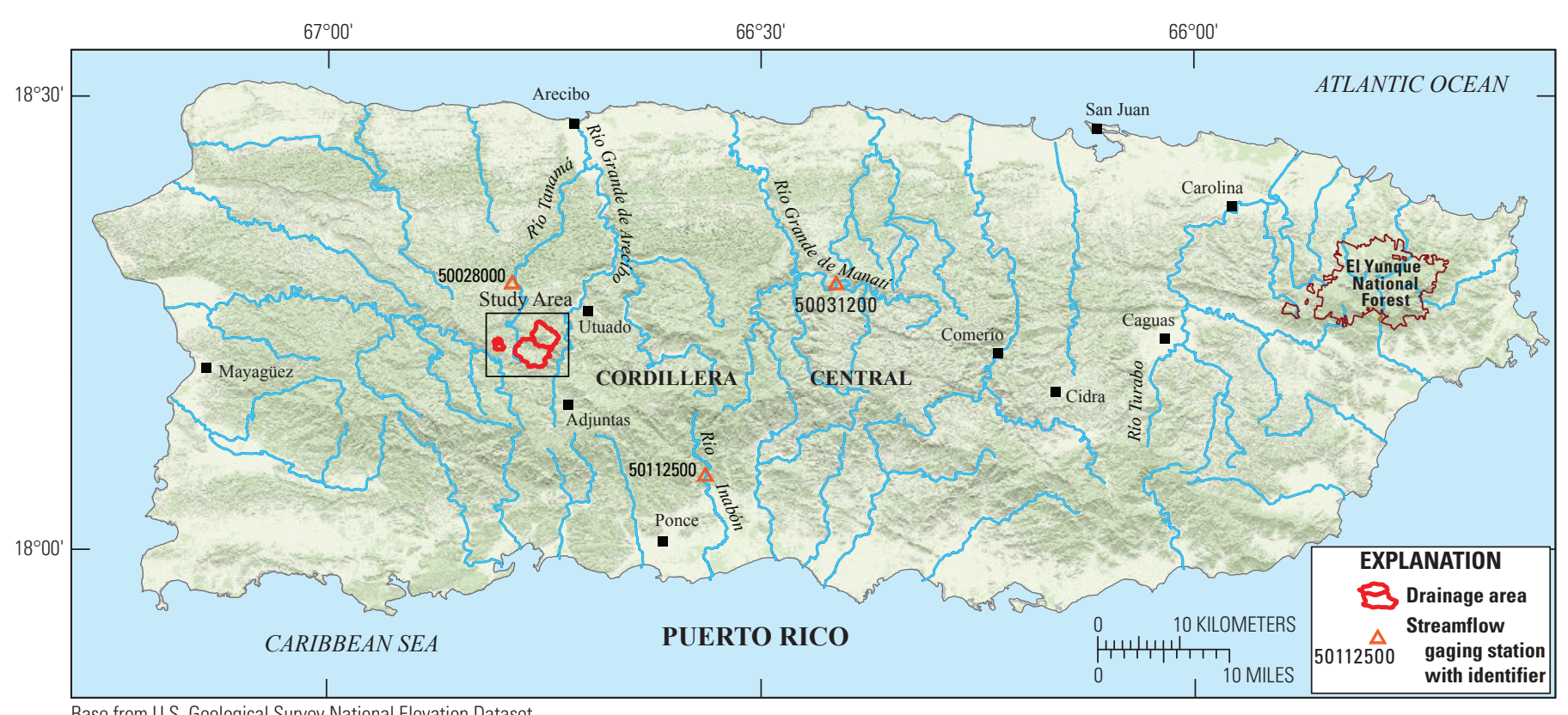

Base from U.S. Geological Survey National Elevation Dataset

Figure 1. Map of Puerto Rico showing the location of the study area in the Cordillera Central mountain range. 
streamflow and forest cover is complex, because streamflow is affected by the stage of forest growth, land-surface slope, drainage density, geology, and other factors. Reducing forest cover (deforestation) or increasing forest cover (afforestation) generally increases or reduces stream runoff, respectively (Bruijnzeel, 1990). Some studies relating changes in forest cover to corresponding changes in the magnitude of base flow have been restricted to areas with overlying coastal and (or) alluvial aquifers where the removal of forest cover has increased low flows in the adjoining stream(s) (Lacey and Grayson, 1998).

Studies examining the role of stemflow (that is, the flow of intercepted water conveyed down the trunk or stem of a plant) as a major source of infiltration into the soil were published by Johnson and Lehmann (2006) and Koichiro and others (2001). Johnson and Lehmann (2006) determined that infiltration of stemflow, which results from the partition of rainfall by the tree canopy, is enhanced by root-induced preferential flow. The amount of precipitation accounted for as stemflow ranged from less than 1 to as much as 22 percent of incident rainfall above the forest canopy where the rainfall averaged 24 to 200 inches per year (in/yr) (610 to 5,080 millimeters per year [mm/yr]). Johnson and Lehmann (2006) also reported that factors such as tree species (including size variations within the same species) and leaf and branch morphology (canopy architecture) influence the amount of stemflow originating from rainfall interception by the tree canopy. Levia and Frost (2003) also studied the hydrologic role of stemflow as a water source to the soil beneath the forest. Manfroi and others (2004) and Germer and others (2010) studied stemflow as a rainfall concentration mechanism beneath the forest cover. Herwitz (1986) reported stemflow rates from 7 to $112 \mathrm{in} / \mathrm{yr}$ (178 to $2,844 \mathrm{~mm} / \mathrm{yr}$ ) for trees in eight montane tropical rainforests in Australia.

A modeling study by $\mathrm{Wu}$ and others (2006) determined that a predominant inverse relation exists between evapotranspiration and altitude at the Luquillo Experimental Forest (El Yunque National Forest), located in northeastern Puerto Rico (fig. 1). This inverse relation may be due to a general decrease in temperature with increasing altitude, which in turn, generally reduces the amount of water consumed by vegetation. Wu and others (2006) did not relate the inverse relation between evapotranspiration and altitude to base-flow magnitude.

Taniguchi and others (1996) determined that although the ratio of stemflow to precipitation is small in a forested basin, the effect of stemflow on groundwater recharge might be relatively large. They also discussed changes in the subsurface water, solute, and heat fluxes induced by changes in land cover and land use that are pertinent to the present study. Taniguchi and others (1996) recognized, however, the inconclusive and even contradictory nature of results from studies that attempt to relate hydrogeologic and geomorphic properties, as well as the extent of forest cover, to base-flow magnitude. The studies cited by Taniguchi and others (1996) were not restricted to a particular altitude range, and included various settings such as coastal plains and mountainous areas. In some of the mountainous areas considered by Taniguchi and others (1996), snowmelt was the dominant or sole water source.

A study in the municipality of Cidra in east-central Puerto Rico indicated the order of magnitude by which afforestation and deforestation affected low flows of streams (Ramos-Ginés, 1997). A low-flow rate of about $0.47\left(\mathrm{ft}^{3} / \mathrm{s}\right) / \mathrm{mi}^{2}$ was estimated for a predominantly forested watershed in the municipio of Cidra. Lower low-flow rates of 0.1 to $0.2\left(\mathrm{ft}^{3} / \mathrm{s}\right) / \mathrm{mi}^{2}$ were estimated for the same municipality from agricultural areas with little or no forest cover. A trend analysis of annual minimum 7-day low flows was performed for the 1972-98 period for the following sites: Río Inabón (USGS station 50112500 on the leeward-facing slope of Cordillera Central), the Río Grande de Manatí (USGS station 50031200 on the windward-facing slope), and Río Tanamá (USGS station 50028000 on the windward-facing slope). Results indicated that low-flow rates increased by about $0.20,0.25$, and $0.31\left(\mathrm{ft}^{3} / \mathrm{s}\right) / \mathrm{mi}^{2}$, respectively, for these sites during the 26-year period (fig. 1; F. Gómez-Gómez, U.S. Geological Survey, written commun., 2006). These increases in low-flow rates, which can be similarly expressed as increases in base flows, may be reasonably attributed to continuous reversion into forest of former agricultural land in the upstream parts of the watersheds for these rivers between 1972 and 1998.

The apparent relation between forest cover and base-flow magnitude of streams in the mountainous interior of Puerto Rico should be of concern prior to establishing land-use practices that require the removal of forest cover. In the mountainous, western half of Puerto Rico, the most common agricultural practice is the replacement of traditional shade coffee plantations with sun coffee at altitudes generally above $1,000 \mathrm{ft}$. In shade coffee plantations, many existing trees are left in place when coffee trees are planted, and in order to obtain a higher-quality product, additional shade trees are planted to ameliorate the effect of solar radiation on the coffee bushes. The quality of coffee beans is higher if they are grown under shade. In contrast, in sun coffee plantations, any vegetation taller than the coffee bushes is removed to maximize the amount of sunlight, with the intent of increasing crop yields. The agricultural practice of replacing shade coffee with sun coffee is based on the belief that the yield per unit area and, thus, the economic benefits of planting sun coffee are higher than the economic benefits obtained from planting shade coffee.

Reductions in forest cover will also lead to a reduction in the hydraulic conductivity of near- surface soils, as documented by Mainuri and Owino (2013). As a result of tree removal, the once shaded clayey soils are exposed to the drying effects of the sun and hardening by the wind. Soil hardening is accompanied by a loss of macroporosity caused by the disappearance of the prior root systems. This alteration - in combination with slopes that range between 40 and 60 percent - reduces water infiltration to the subsurface and increases rapid soil erosion and rainfall runoff. 


\section{Purpose and Scope}

This report documents whether there is a measurable relation between the spatial extent of forest cover and the magnitude of base flow at selected basins within the mountainous interior of Puerto Rico. Two sets of paired basins of the Río Grande de Arecibo were studied within the municipalities of Utuado and Adjuntas in the mountainous interior of Puerto Rico (fig. 1). The study was conducted between June 1, 2008, and September 30, 2011. The results obtained provide information that can contribute to sustainable development and conservation of water resources within the municipios of Adjuntas and Utuado; however, the results could be extrapolated to similar areas elsewhere in Puerto Rico.

\section{Approach}

The relation between the magnitude of base flows and the extent of forest cover was studied in drainage basins of the Río Tanamá and Río Guaónica within the municipio of Adjuntas and Utuado, Puerto Rico (figs. 1 and 2). These paired basins were chosen principally because they are similar in areal extent ( 3.78 and 2.52 square miles [ $\left.\mathrm{mi}^{2}\right]$, respectively) and both lie within the mountainous interior of Puerto Rico. The basins are also similar in topographic slope, aspect, and rainfall pattern, and they differ principally in the extent of mature forest cover. The Río Tanamá Basin has more diversified land use and a smaller extent of forest cover than the Río Guaónica Basin. The influence of basin size on the magnitude of surface-water runoff was accounted for by normalizing base flow by basin area. Additionally, streamflow at a second set of paired smaller basins within the watershed of the Río Coabey, a tributary of the Río Tanamá was examined. Streamflow in the smaller paired basins was measured at two sites, herein designated as Tributary $1\left(0.27 \mathrm{mi}^{2}\right)$ and Tributary $2\left(0.15 \mathrm{mi}^{2}\right)$ (fig. 2). Both tributary basins are an order of magnitude smaller than the Río Tanamá and Río Guaónica basins. The smaller basins differ in land use and in the extent of forest cover, but are similar in geological substrate, topographic slope, aspect, and rainfall pattern. The Tributary 1 basin has more diverse land use than Tributary 2, and includes sun and shade coffee plantations, patches of forest, plots of plantains and other minor cash crops, and houses. The basin of Tributary 2 consists largely of sun coffee plantations interspersed with crops such as plantains and citrus.

\section{Description of the Study Area}

The study area lies within the western interior of the Cordillera Central mountain range of Puerto Rico in tributary streams of the Río Grande de Arecibo (fig. 1). The east-west trending Cordillera Central mountain range is the most prominent topographic feature of Puerto Rico. The mountain range has an average altitude of about 2,300 ft above mean sea level (all altitude measurements herein are referenced to mean sea level) along the insular hydrologic divide and acts as a barrier to the prevalent northeast trade winds. As a consequence, rainfall is distributed unevenly between the northern and southern coasts of Puerto Rico, with north-facing slopes receiving almost twice as much rainfall as the southfacing slopes. Temperature follows a seasonal pattern, with the minimum occurring between December and February, averaging $12^{\circ} \mathrm{C}\left(54^{\circ} \mathrm{F}\right)$, and the maximum occurring between June and August, averaging $29^{\circ} \mathrm{C}\left(85^{\circ} \mathrm{F}\right)$. Solar radiation follows a seasonal pattern similar to that of temperature, with the minimum insolation in December and maximum insolation in June. The predominant wind direction is from the northeast.

The topography of the study area is characterized by moderate to steep slopes ranging from 40 to 60 percent. The geologic substrate consists mostly of volcanoclastic and intrusive rocks, with subordinate lavas that range from Late Cretaceous to Early Tertiary in age. The main geological structural elements within the study area are faults and folds oriented predominantly southwest to northeast. Most of the land in the study area is in forest cover with mixed cultivation of sun and shaded coffee orchards and associated crops, such as plantains, bananas, and citrus fruits.

\section{Landforms and Drainage}

The study area is divided into two sets of paired basins (fig. 2). The larger paired basins are tributaries in the headwaters of the Río Guaónica and Río Tanamá (fig. 3). Landsurface altitude within the Río Guaónica Basin ranges from $876 \mathrm{ft}$ (267 meters [m]) at gaging station 50027880 to $2,820 \mathrm{ft}$ $(860 \mathrm{~m})$ at its headwaters, with a maximum altitude of $3,050 \mathrm{ft}$ (930 $\mathrm{m}$ ) at Cerro (Pico) Roncador. In the Río Tanamá Basin, land-surface altitude ranges from about $1,870 \mathrm{ft}(570 \mathrm{~m})$ at gaging station 50027850 to $2,820 \mathrm{ft}(860 \mathrm{~m})$ at the headwaters of Río Tanamá, with a maximum altitude of 3,080 ft (939 m) at Cerro Novillo. Within the smaller basins of the Río Coabey, land-surface altitude ranges from $1,800 \mathrm{ft}(550 \mathrm{~m})$ at both gaging stations (50027820 and 50027830) to a maximum of $2,330 \mathrm{ft}(710 \mathrm{~m})$ in the largely sun coffee basin (Tributary 2 ) and 2,200 $\mathrm{ft}(670 \mathrm{~m})$ at in the largely forested/shade coffee basin (Tributary 1) (fig. 4). Important morphological characteristics of the basins are listed in table 1 . The larger paired basins average about $3 \mathrm{mi}^{2}$ in area, which is an order of magnitude larger than the smaller basins.

\section{Surface Geology}

The study area is underlain by the Late-Cretaceous through early-Tertiary age Anón and Maricao Formations, and locally, by minor intrusive bodies of porphyritic quartz diorite of early Tertiary age (fig. 5; Nelson, 1967; Nelson and Tobisch, 1968; Mattson, 1968; Krushensky and Curet, 1984). The Anón and Maricao Formations consist of volcaniclastics, breccia, tuffaceous sandstone, siltstone, and mudstone, with subordinate lava flows. Field examination of outcrops 


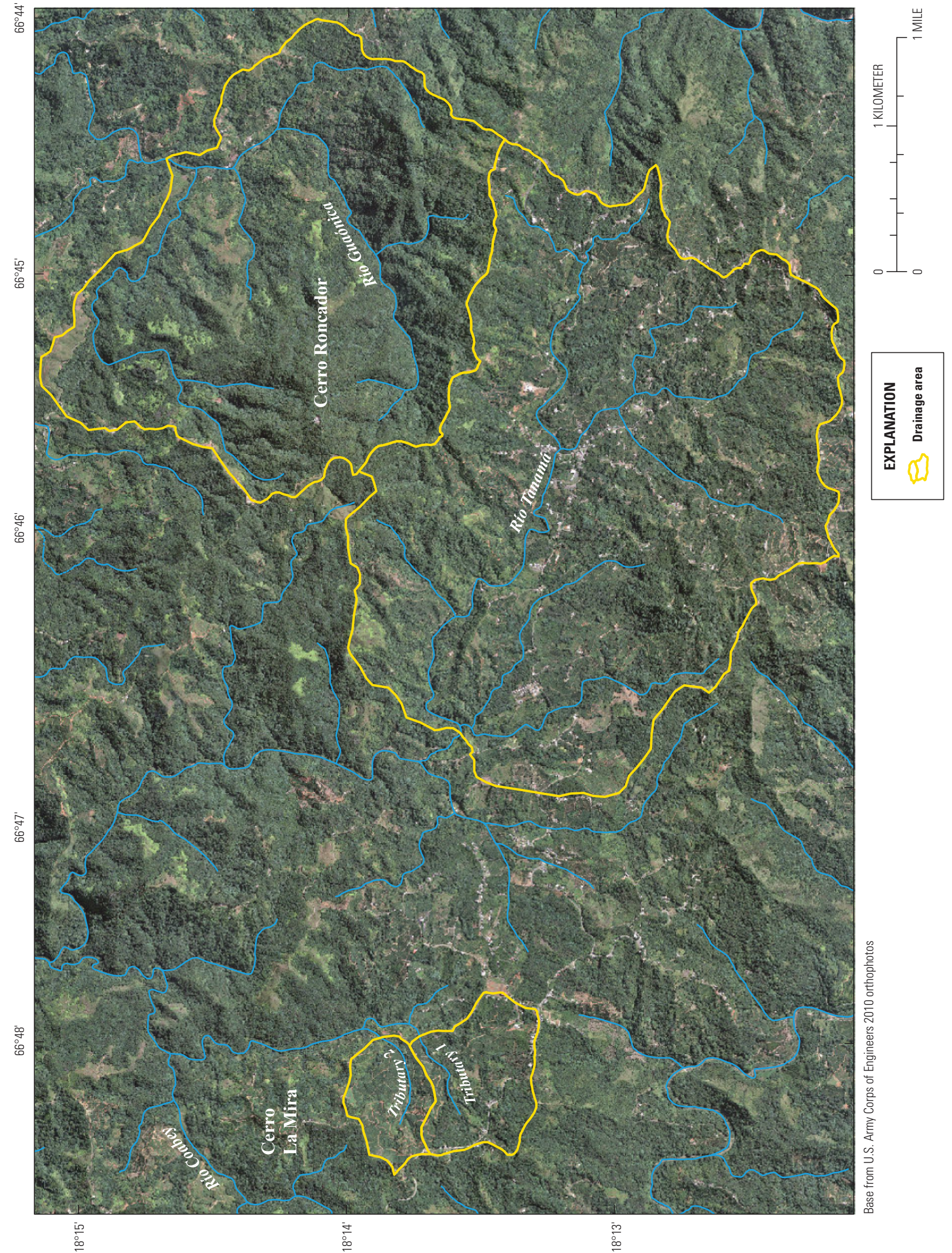

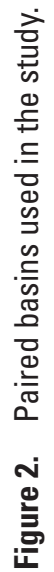




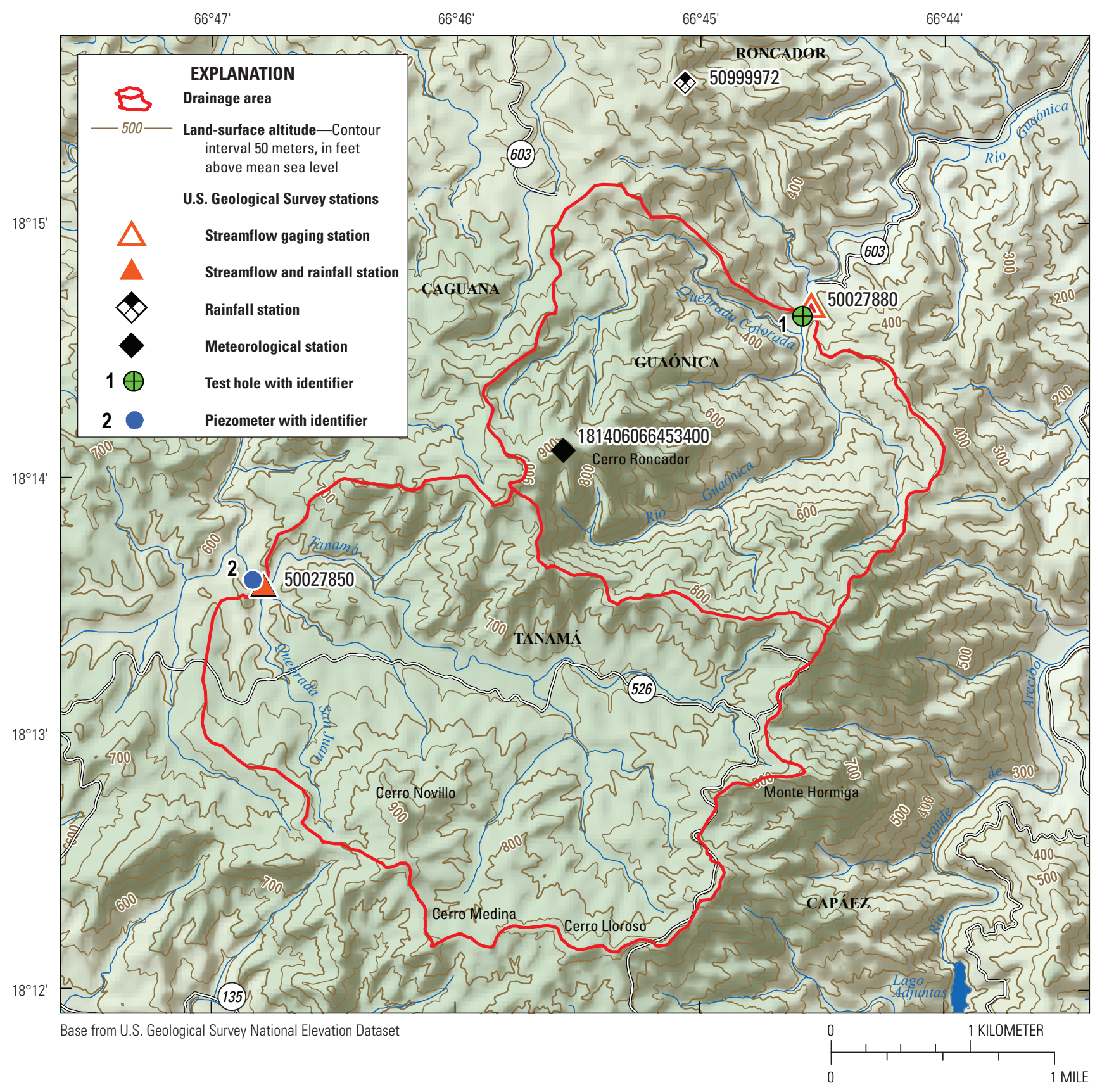

Figure 3. Subbasins of Río Guaónica and Río Tanamá with data collection sites. 


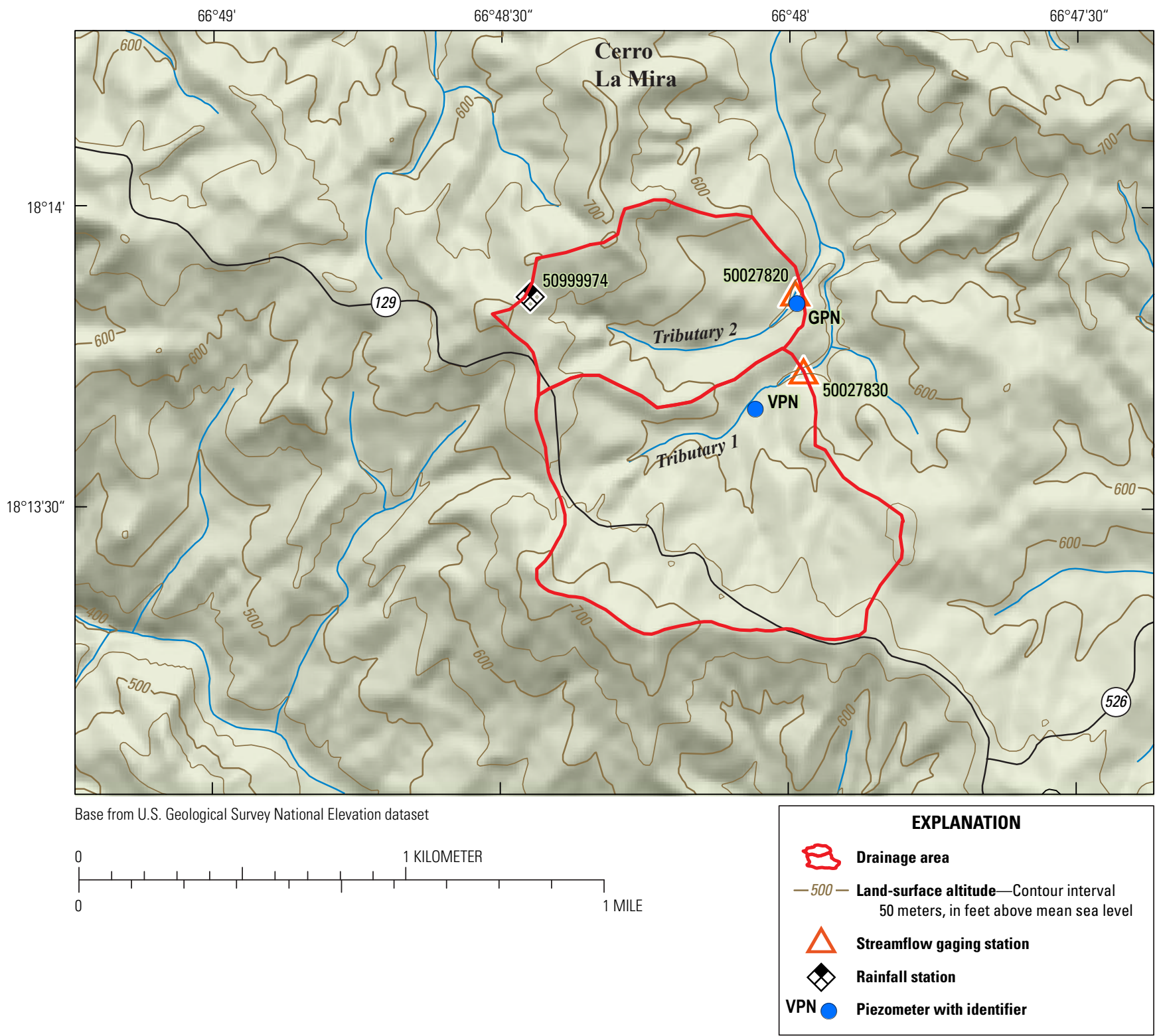

Figure 4. Subbasins of Tributary 1 and 2 in the Rio Coabey Basin with data collection sites.

Table 1. Characteristics of study area basins.

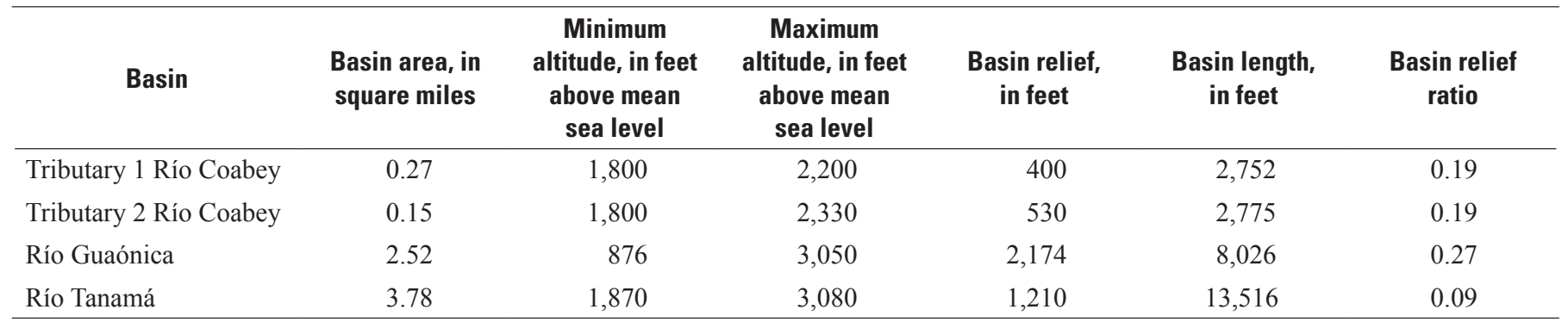




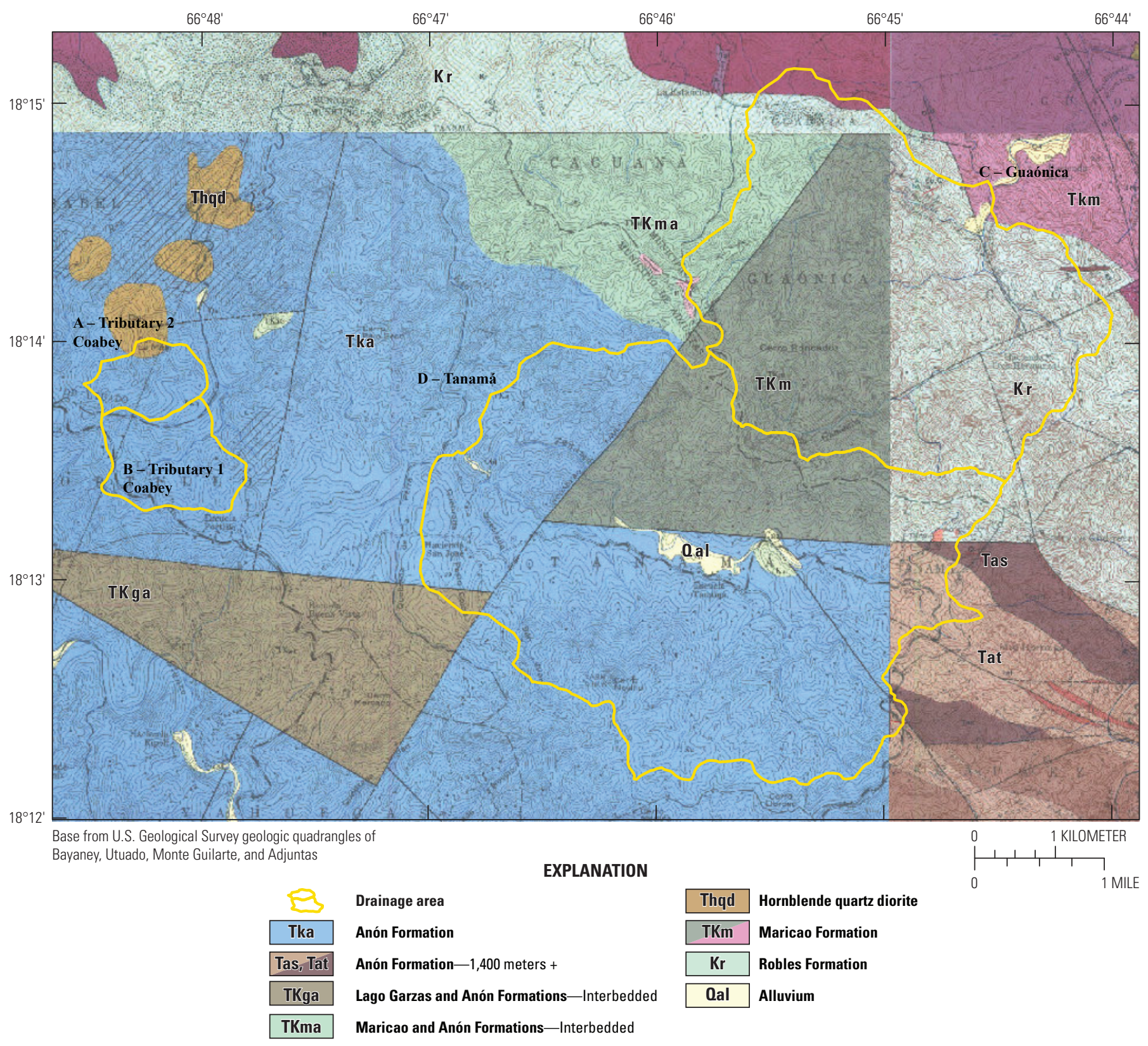

Figure 5. Surface geology of the two sets of paired basins in the study area.

indicates that the Anón and Maricao Formations generally saprolitize with time into a massive light- to medium-orangered, silty and slightly sandy claystone. The rocks of the Anón and Maricao Formations within the study area are predominantly cut and offset by left-lateral faults (Krushensky and Curet, 1984). An isolated, small alluvial deposit of Quaternary age having a length of about 3,500 ft and average width of $330 \mathrm{ft}$ crops out in the Río Tanamá Basin (fig. 5).

\section{Soils}

The soils within the two paired sets of basins consist of Humatas clay. These are mostly deep and predominantly clayey and silty in texture, with 40 to 60 percent slope
(U.S. Department of Agriculture Natural Resources Conservation Service, n.d.). These soils are moderately to slowly permeable, mostly formed in fine-textured residuum weathered from basic igneous rocks, and are restricted to humid tropical climates.

\section{Methods of Investigation}

To assess how land-use practices, such as deforestation and shade or sun coffee cultivation, affect base flows of streams, data were obtained to describe land use, rainfall distribution and other climate indicators, streamflow, evapotranspiration, and groundwater. 


\section{Land-Use Classification}

The land-use data used in this study were obtained from an aerial-photographic survey of Puerto Rico conducted by the U.S. Forest Service (USFS) during 1991-92 (Helmer and others, 2002). The analysis of the aerial photographs, including their field verification, was completed by USFS personnel. To simplify analysis and to meet the objectives of this study, the categories of land use defined by the USFS were generalized into three type groups shown in table 2.

The main criterion used to differentiate the various land uses in the study area in these type groups was their similarity, such as in the height and extent of forest canopy in the case of vegetative covers and the predominance of a paved, impervious surface devoid of vegetation in the case of commercial and rural residential zones. Maps used for land-use classifications were prepared by the USGS Caribbean-Florida Water Science Center showing the distribution of these three type groups of land use within the two sets of paired basins used in this study. The percentage of land use within each of these three type groups in each basin was determined from the maps.

\section{Rainfall}

Rainfall data were collected at an altitude of about 2,900 ft from an existing rainfall station (Barrio Roncador, USGS station ID 50999972) maintained by the USGS as part of an island-wide network (fig. 3). Three additional rainfall stations equipped with tipping-bucket-type rainfall gages were installed as part of this study at different altitudes to account for the spatial variation in rainfall within the two sets of paired basins: Pico Roncador meteorological station at 2,952 ft; Río Tanamá rainfall station at $1,870 \mathrm{ft}$; and La Mira rainfall station at 1,800 ft (figs. 3 and 4; table 3). Additional climatological data were measured during the study period at the Pico Roncador meteorological station. Rainfall and additional climatological data are available in Rodríguez-Martínez and Santiago (2017).

\section{Streamflow}

Streamflow gaging stations were installed in the two sets of paired basins to collect continuous streamflow data (figs. 3, 4, and 6; table 3). As a result of the steep slope of the stream channels and the steep hydraulic gradient at the two sets of paired basins, runoff occurred rapidly. Therefore, only relatively low-stage streamflow discharge measurements were available for analysis. Restricting the available field discharge measurements to low streamflow conditions was not considered a hindrance to meeting the objectives of the study, however, because the emphasis of the investigation was to characterize the occurrence of low flows (K. Ries, U.S. Geological Survey, written commun., 2012).

Calendar year 2010 (herein referred to as 2010) is the only full year for which streamflow was available for both paired basins, and is the focus of this study. Continuous daily streamflow data were estimated for the larger paired basins (Rio Tanamá and Rio Guaónica) (Rodríguez-Martínez and Santiago, 2017). Continuous streamflow data for the tributaries of Río Coabey were not estimated, given the extremely transient nature of storm runoff events. Therefore, only the discrete discharge measurements made during 2010 (Rodríguez-Martínez and Santiago, 2017) and not estimated continuous discharge values, were used to provide an estimate of the seasonal variation in the flow at the two tributaries of the Río Coabey. No discrete measurements were made during storm events.

Total streamflow was separated into base-flow and runoff components. The base-flow component of continuous streamflow estimated at each of the two larger basins was obtained with the computer program Web-based Hydrograph Analysis Tool (WHAT), developed by Lim and others (2005). The base-flow component was computed using the "One-parameter Digital Filter" option (parameter specified as 0.925) included in WHAT. This option takes into consideration the duration of the runoff, which affects the computed base-flow magnitude. WHAT cannot be used to process discrete streamflow data, such as the non-continuous streamflow measurements available for the two smaller basins. The small area of these basins restricts direct runoff to less than an hour after rainfall events; therefore, measured streamflows were assumed to be entirely composed of base flow. To integrate the seasonal variations in base flow, the annual mean discharge at the larger basins was calculated as the average of the daily data, whereas at the smaller basins the annual mean discharge was assumed equal to the average of the discrete measurements. To compare the base-flow-generation capacities between basins in the same paired set, flows were normalized by drainage area and presented as cubic feet per second per square mile. Results of the WHAT analysis are available in Rodríguez-Martínez and Santiago (2017).

Table 2. Land-use type groups.

[Land-use categories defined by the U.S. Forest Service (Helmer and others, 2002)]

\begin{tabular}{cc}
\hline Group & Characteristics \\
\hline Type I & $\begin{array}{c}\text { Forest patches, shade coffee and mixed shade and sun coffee with associated plantain and } \\
\text { banana crops (cash crops) }\end{array}$ \\
Type II & $\begin{array}{l}\text { Pastures, sun coffee with cash crops; bushes and grassland (agricultural other than shade coffee) } \\
\text { Type III }\end{array}$ \\
$\begin{array}{c}\text { Built-up areas (low density residential; commercial; high density residential; recreational or } \\
\text { public-use zones (urban) }\end{array}$ \\
\hline
\end{tabular}


Table 3. Data-collection sites, type, and coordinates.

[Data from these stations are available in Rodriguez-Martinez and Santiago (2017). Latitude and longitude, in decimal degrees, were measured with global positioning systems; datum is North American Datum of 1927; USGS, U.S. Geological Survey]

\begin{tabular}{|c|c|c|c|c|}
\hline $\begin{array}{l}\text { USGS ID number (see } \\
\text { figures } 3,4 \text {, and } 6 \\
\text { for location) }\end{array}$ & Name & Station type & Latitude & Longitude \\
\hline $181438066443600(1)$ & Río Guaónica well (RGu) & Groundwater & $18^{\circ} 14^{\prime} 38.2^{\prime \prime}$ & $66^{\circ} 44^{\prime} 35.6^{\prime \prime}$ \\
\hline $181336066465000(2)$ & Río Tanamá well (PRT) & Groundwater & $18^{\circ} 13^{\prime} 36.0^{\prime \prime}$ & $66^{\circ} 46^{\prime} 50.0^{\prime \prime}$ \\
\hline $181350066475900(3)$ & $\begin{array}{l}\text { Gir deep well (GPN) } \\
\text { (PGiD, deep and PGiS, shal- } \\
\text { low) }\end{array}$ & Groundwater & $18^{\circ} 13^{\prime} 50.4^{\prime \prime}$ & $66^{\circ} 47^{\prime} 59.2^{\prime \prime}$ \\
\hline $181340066480400(4)$ & $\begin{array}{l}\text { Viequense } 1 \text { deep well (VPN) } \\
\text { (PVD, deep and PVS, shallow) }\end{array}$ & Groundwater & $18^{\circ} 13^{\prime} 39.9^{\prime \prime}$ & $66^{\circ} 48^{\prime} 03.5^{\prime \prime}$ \\
\hline 181406066453400 & Pico Roncador station & Meteorological & $18^{\circ} 13^{\prime} 59.4^{\prime \prime}$ & $66^{\circ} 45^{\prime} 32.52^{\prime \prime}$ \\
\hline 50999972 & $\begin{array}{l}\text { Barrio Roncador rainfall sta- } \\
\text { tion }\end{array}$ & Rainfall & $18^{\circ} 14^{\prime} 06.5^{\prime \prime}$ & $66^{\circ} 45^{\prime} 33.7^{\prime \prime}$ \\
\hline 50027820 & $\begin{array}{l}\text { Tributary } 2 \text { of Río Coabey near } \\
\text { Adjuntas }\end{array}$ & Streamflow & $18^{\circ} 13^{\prime} 51.5^{\prime \prime}$ & $66^{\circ} 47^{\prime} 59.4^{\prime \prime}$ \\
\hline 50027830 & $\begin{array}{l}\text { Tributary } 1 \text { of Río Coabey near } \\
\text { Adjuntas }\end{array}$ & Streamflow & $18^{\circ} 13^{\prime} 43.70^{\prime \prime}$ & $66^{\circ} 47^{\prime} 58.4^{\prime \prime}$ \\
\hline 50027880 & Río Guaónica near Utuado & Streamflow & $18^{\circ} 14^{\prime} 40.78^{\prime \prime}$ & $66^{\circ} 44^{\prime} 32.92^{\prime \prime}$ \\
\hline 50028000 & Río Tanamá near Utuado & Streamflow & $18^{\circ} 18^{\prime} 02^{\prime \prime}$ & $66^{\circ} 46^{\prime} 58^{\prime \prime}$ \\
\hline
\end{tabular}

\section{Evapotranspiration}

The mass-balance approach of Giusti (1978) was used to estimate evapotranspiration (ET) within the study area. In this approach, ET is considered to be the difference between rainfall and runoff $(\mathrm{ET}=\mathrm{P}-\mathrm{RO})$ where $\mathrm{P}$ is the basin average precipitation and RO is runoff. According to Giusti (1978), ET increases until a threshold in rainfall is reached, beyond which it progressively decreases with further increases in rainfall. Annual ET values during 2010 were obtained for the two larger study basins from the measured streamflow exiting these basins (USGS stations Río Tanamá near Tanamá and Río Guaónica near Utuado) and the annual rainfall gaged at the USGS station at Barrio Roncador (fig. 3; table 3). The rainfall and streamflow data used to estimate evapotranspiration are available in Rodríguez-Martínez and Santiago (2017).

\section{Groundwater}

A test hole was drilled and a series of piezometers were installed in each of the two sets of paired basins to obtain the lithologic and groundwater data needed to define the hydrogeology of the study area (table 3, figs. 3 and 4; Lapham and others, 1997). A test hole was drilled in the Río Guaónica Basin, and a single piezometer was installed in the Río Tanamá Basin. Stratified nests of piezometers having shallow and deep monitoring intervals were installed in basins of Tributary 1 and 2 . The diameter of boreholes for the piezometers was 6 in. The piezometers were installed within 4-in.-diameter, schedule-40 polyvinyl chloride (PVC) pipe, with 0.010 -in.-slotted, schedule-40 PVC pipe (slotted screens) set within the bottom $5 \mathrm{ft}$ of the piezometer. The annular area along the screened sections was backfilled with inert silica sand and capped by a 1-ft-thick bentonite seal. The annular region above the bentonite seal was backfilled to land surface with a neat cement mix. Water-level measurements were made at irregular intervals, and a slug test was conducted at one of the piezometers representative of the more transmissive subsurface unconsolidated sediments to estimate hydraulic conductivity $\left(\mathrm{K}_{\text {saa }}\right)$. The analysis method of Bouwer and Rice (1976) was used to compute $\mathrm{K}_{\text {sat }}$ values from the slug-test data. Groundwater data are available in Rodríguez-Martínez and Santiago (2017).

\section{Effects of Forest Cover on Base Flow of Streams}

Land use in the two sets of paired basins is described along with the prevailing hydrogeologic conditions of the study area and the base-flow hydrology within each set of paired basins. Based on previous studies and results obtained in this study, the rationale for the relation between the extent of forest cover and the magnitude of base flow at a mountainous basin is presented and discussed. 


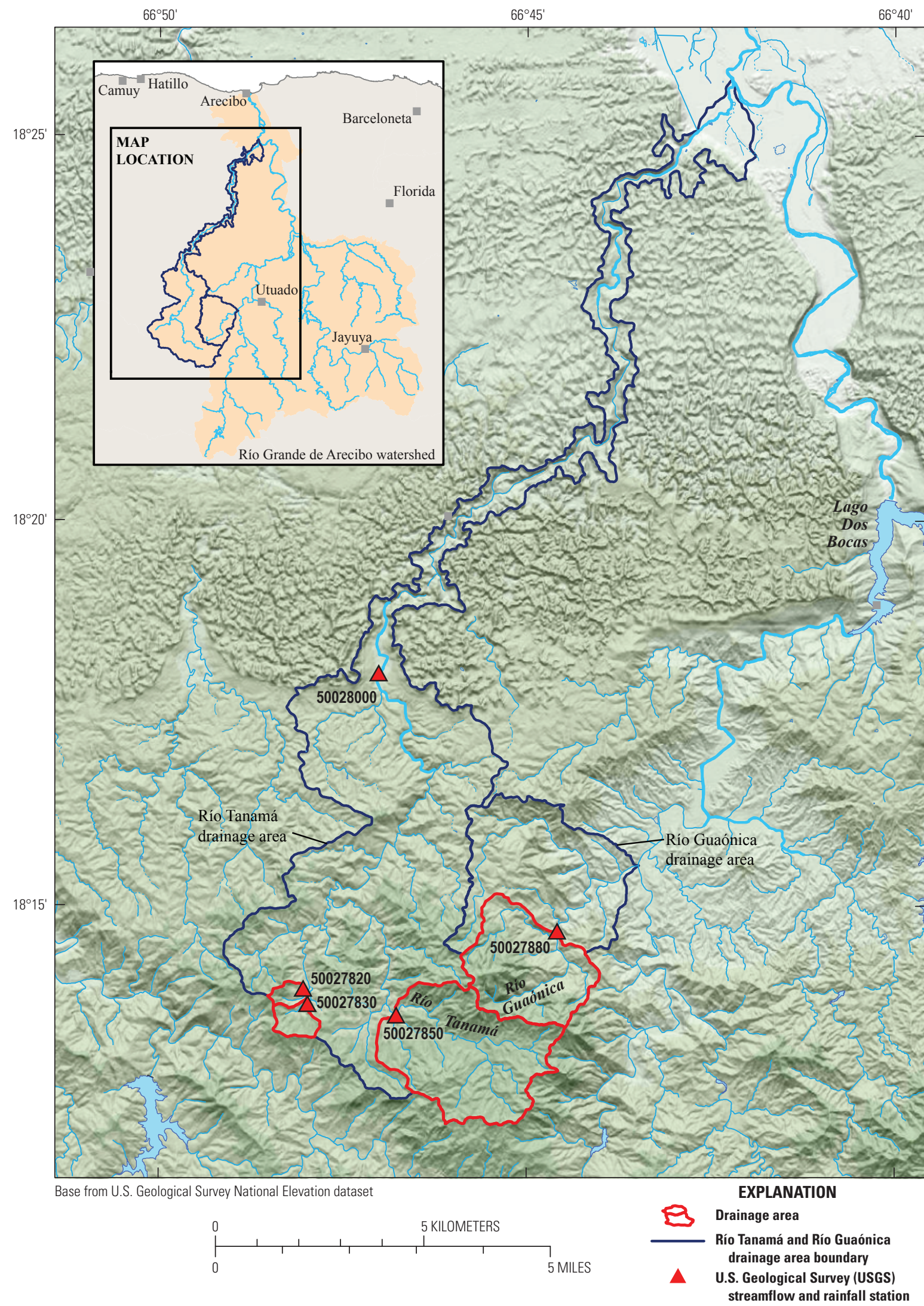

Figure 6. Location of USGS streamflow gaging stations in study area. 


\section{Land-Use Analysis}

The extent and spatial distribution of the three type groups of land use in the study area were determined, as defined from the USFS 1991-92 survey (Helmer and others, 2002; fig. 7, table 4). The Tributary 1 and Tributary 2 paired basins differ considerably from each other in the percentage of Type I and Type II groups. Tributary 1 has a higher percentage of Type I group land use (52 percent) than Tributary 2 (15 percent), particularly in the forest with shade coffee component. Tributary 2 has a much higher percentage of the Type II group of land use ( 84 percent), with a high prevalence of sun coffee, than Tributary 1 (46 percent). Likewise, the Río Guaónica Basin has a higher percentage cover of the Type I group ( 81 percent), with shade coffee and forest as the main components, than the Río Tanamá Basin (59 percent).

\section{Rainfall and Climate}

Rainfall data from the Pico Roncador and Rio Tanamá stations were not considered because the rainfall record was incomplete. The rainfall station at La Mira was used as the rainfall data reference for the smaller paired basins (Tributaries 1 and 2), and the rainfall station at Barrio Roncador was used as the rainfall data reference for the large paired basins (Rio Tanamá and Rio Guaónica).

In general, annual rainfall distribution within the study area during 2010 followed a seasonal pattern (fig. 8). Total annual rainfall at the La Mira and the Barrio Roncador stations during 2010 was about 81 and 96 in., respectively. Comparing rainfall data for 2010 with the long-term normal for the area indicates rainfall was higher than the 1981-2010 normal of about 78 in. (National Weather Service, n.d.). The difference in rainfall between the paired basins was assumed to have a negligible effect on the appraisal of land cover effects on base flow.

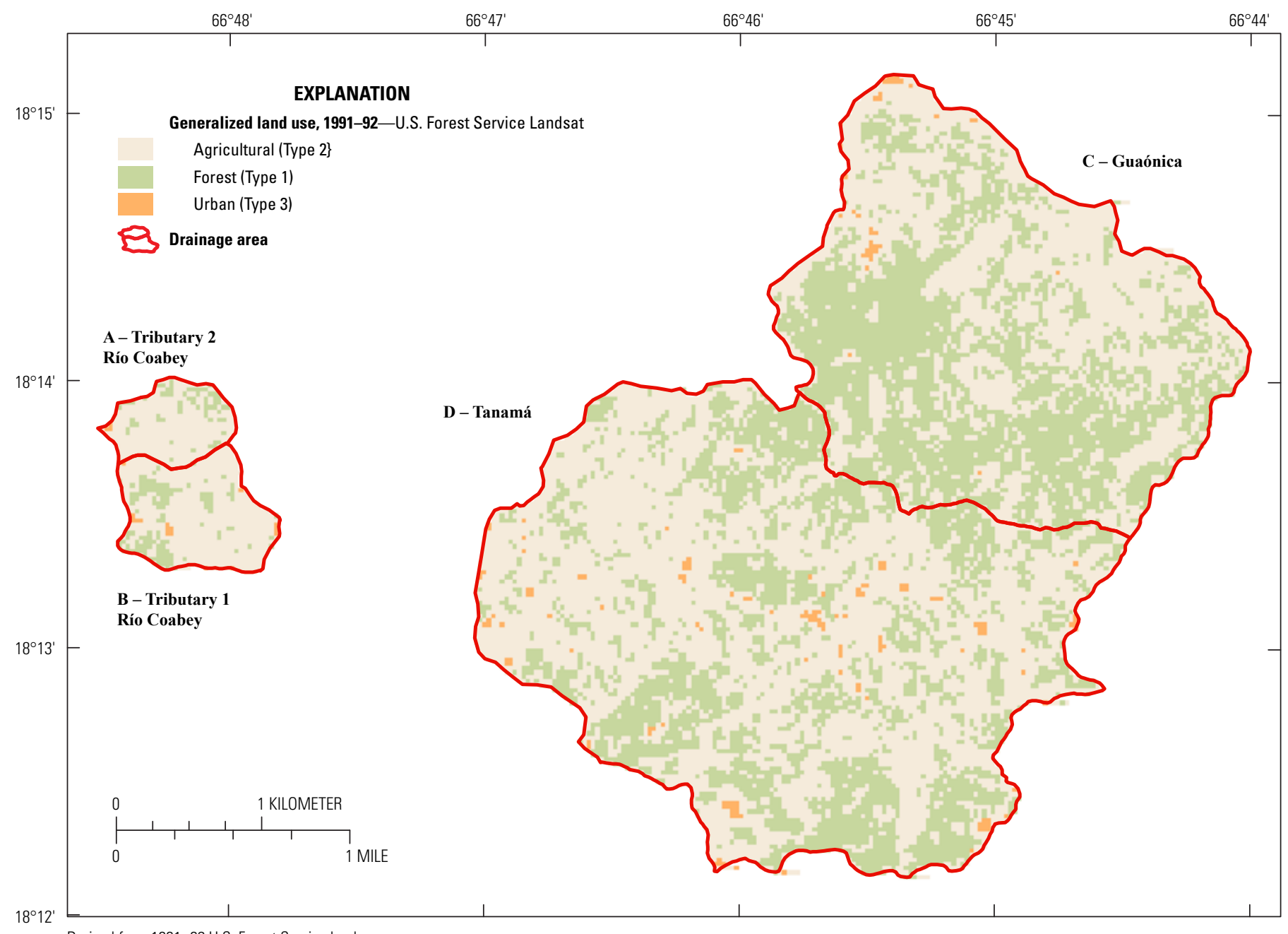

Derived from 1991-92 U.S. Forest Service land cover

Figure 7. Spatial distribution of the main land-use type classification in the two paired basins. 
Table 4. Areal extent of basins and percentage of land-use type classification within each of the paired basins.

\begin{tabular}{lcccc}
\hline $\begin{array}{c}\text { Basin identification } \\
\text { (fig. 2) }\end{array}$ & $\begin{array}{c}\text { Areal extent of basin, } \\
\text { in square miles }\end{array}$ & $\begin{array}{c}\text { Percentage of basin } \\
\text { with Type I group } \\
\text { of land uses }\end{array}$ & $\begin{array}{c}\text { Percentage of basin } \\
\text { with Type II group } \\
\text { of land uses }\end{array}$ & $\begin{array}{c}\text { Percentage of basin } \\
\text { with Type III group } \\
\text { of land uses }\end{array}$ \\
\hline Tributary 1 Río Coabey* & 0.27 & 52 & 46 & 2 \\
Tributary 2 Río Coabey* & 0.15 & 15 & 84 & 0.7 \\
Río Guaónica** & 2.52 & 81 & 18 & 1 \\
Río Tanamá** & 3.78 & 59 & 40 & 1 \\
\hline
\end{tabular}

*/** Components of the same paired set of basins.

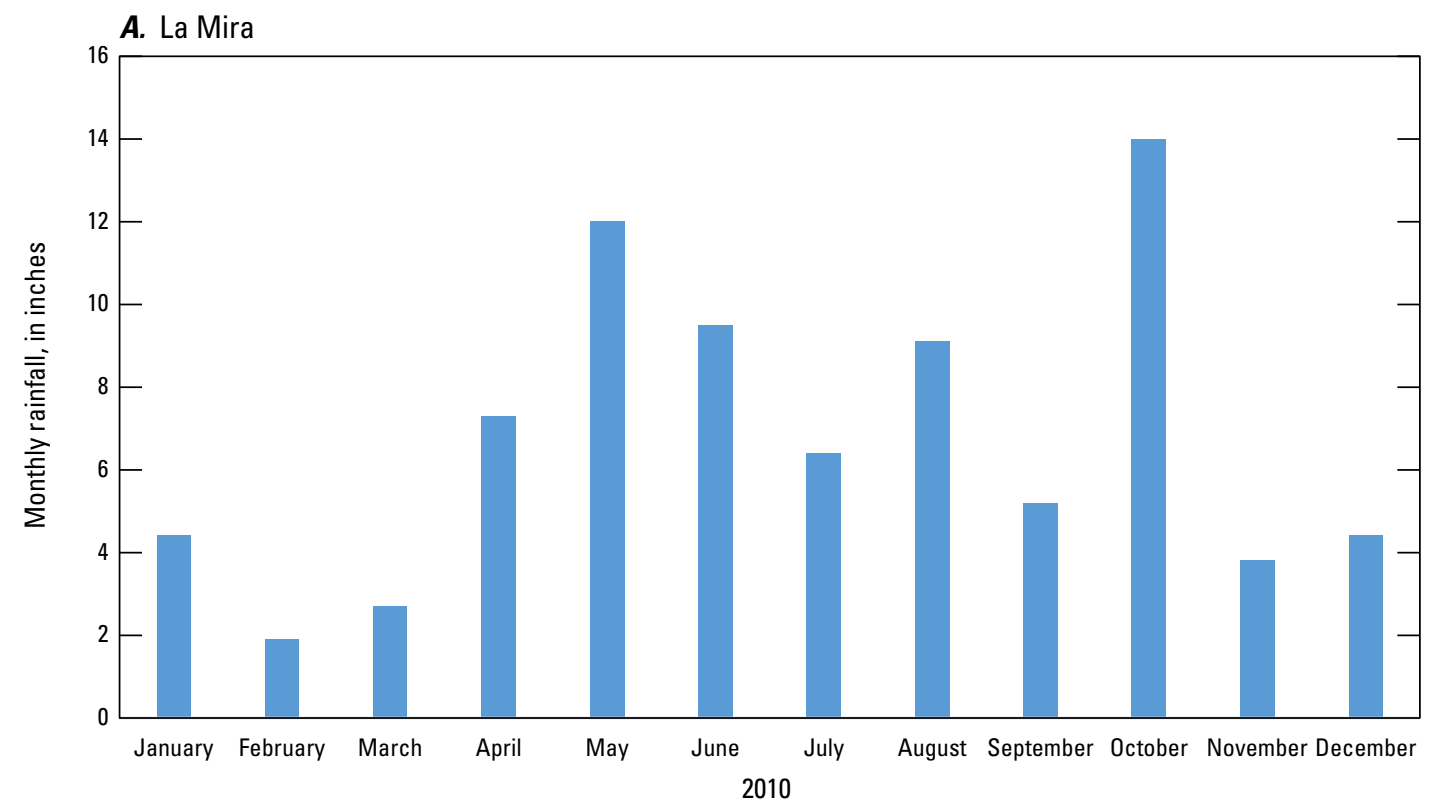

B. Barrio Roncador

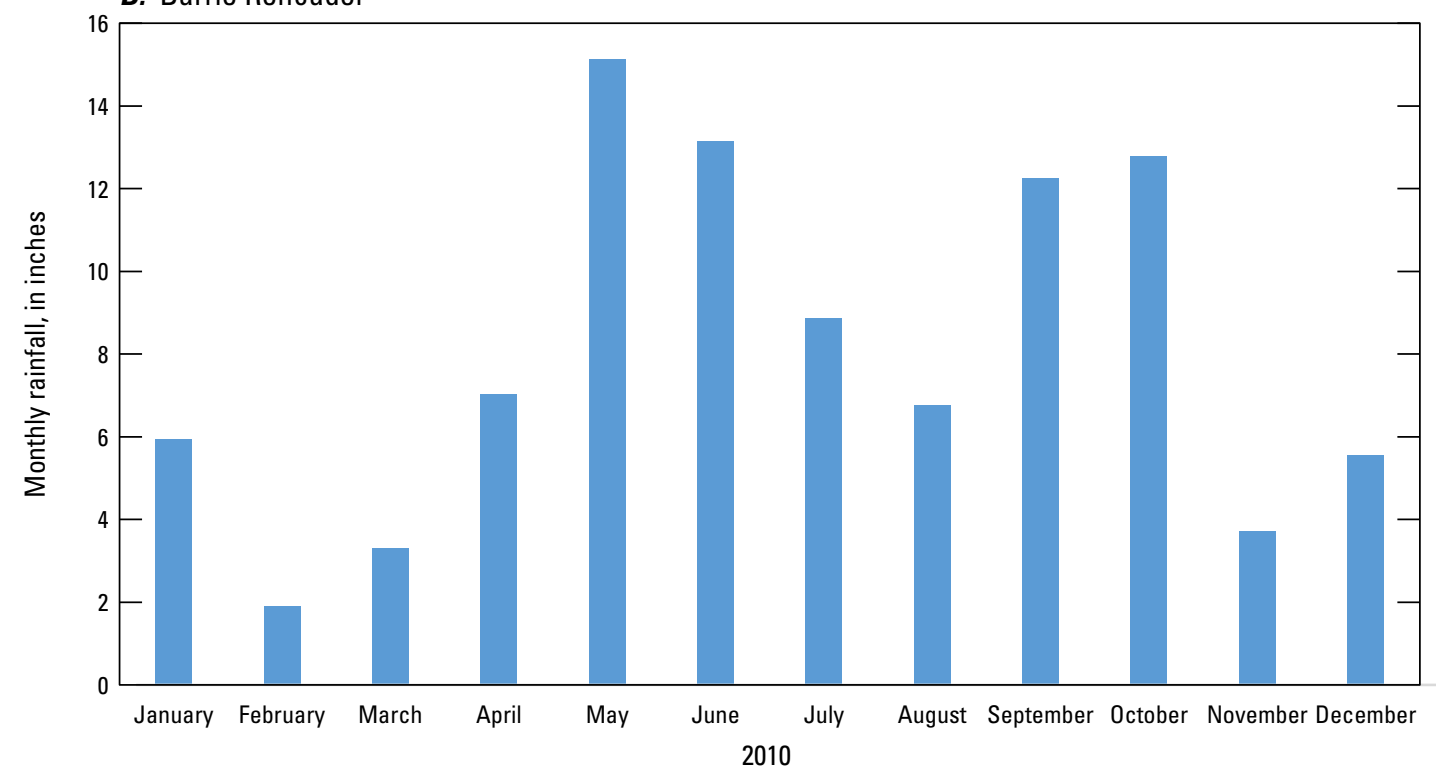

Figure 8. Monthly rainfall during 2010 at the, $A$, La Mira, and B, Barrio Roncador rainfall stations. 
Ancillary meteorological data were monitored at the Pico Roncador station. Monthly average temperature during 2010 ranged from $18.6^{\circ} \mathrm{C}$ in December to $21.7^{\circ} \mathrm{C}$ in July, with a daily minimum of $14.6^{\circ} \mathrm{C}$ in March and daily maximum of $23.5^{\circ} \mathrm{C}$ in July. The lowest and highest daily average maximum wind speeds were 5 and 18 miles per hour $(\mathrm{mi} / \mathrm{h})$, respectively. The daily average wind directions were mostly from the northeast (less than 90 degrees) and less frequently from the southeast, with bearings ranging between 90 and 180 degrees. The lowest and highest daily means in incoming solar radiation were 38 and 298 watts per square meter $\left(\mathrm{W} / \mathrm{m}^{2}\right)$, respectively. The lowest and highest daily means in air pressures monitored at the $3,215 \mathrm{ft}(980-\mathrm{m})$ altitude of the Pico Roncador station were 26.77 in. (680 millimeters [mm]) and 27.09 in. $(688 \mathrm{~mm})$ of mercury $(\mathrm{Hg})$, respectively. The daily mean relative humidity ranged from a minimum value of 77 percent to a maximum of 99 percent.

\section{Hydrogeology}

Overall, the underlying strata in the study area consist primarily of silt and clay-sized unconsolidated deposits along with stratified beds of clayey sand, and silty clay (fig. 9). The water-bearing zones are restricted to thin strata (from 2 to $7 \mathrm{ft}$ thick) of silty and clayey fine-grained sandstone. The high clay and silt content of the surficial deposits substantially limits the water-bearing and transmissive properties of the saturated zone. A slug test conducted at piezometer Viequense Deep (fig. 4), considered representative of the more permeable unconsolidated deposits, indicated a hydraulic conductivity $\left(\mathrm{K}_{\mathrm{sat}}\right)$ range of 2.2 to 2.5 feet per day (ft/d). In the vicinity of Río Guaónica, drilling penetrated the granodiorite bedrock below a depth of $14 \mathrm{ft}$ (fig. 9). Within the granodiorite basement, fracture sets with disseminated pyrite and iron oxide stains are present. These fractures, particularly those with iron oxide stains (an indication of precipitation of dissolved iron from the overlying unconsolidated deposits), might provide storage and pathways for groundwater movement. Groundwater at all piezometers was found to be under confined conditions, which is a result of the steep topography and the confining effect of the clay and silt on the water-bearing zones. Groundwater levels at selected piezometers ranged from 12.89 to $25.0 \mathrm{ft}$ below land surface datum (blsd) at piezometer Girau Deep and from 11.71 to $20.00 \mathrm{ft}$ blsd at piezometer Río Tanamá (table 5).

\section{Evapotranspiration Estimate}

Rainfall at the Barrio Roncador station, in the vicinity of the larger paired basins, was about 96 in. in 2010. Using this rainfall value, and the 2010 average, measured streamflow

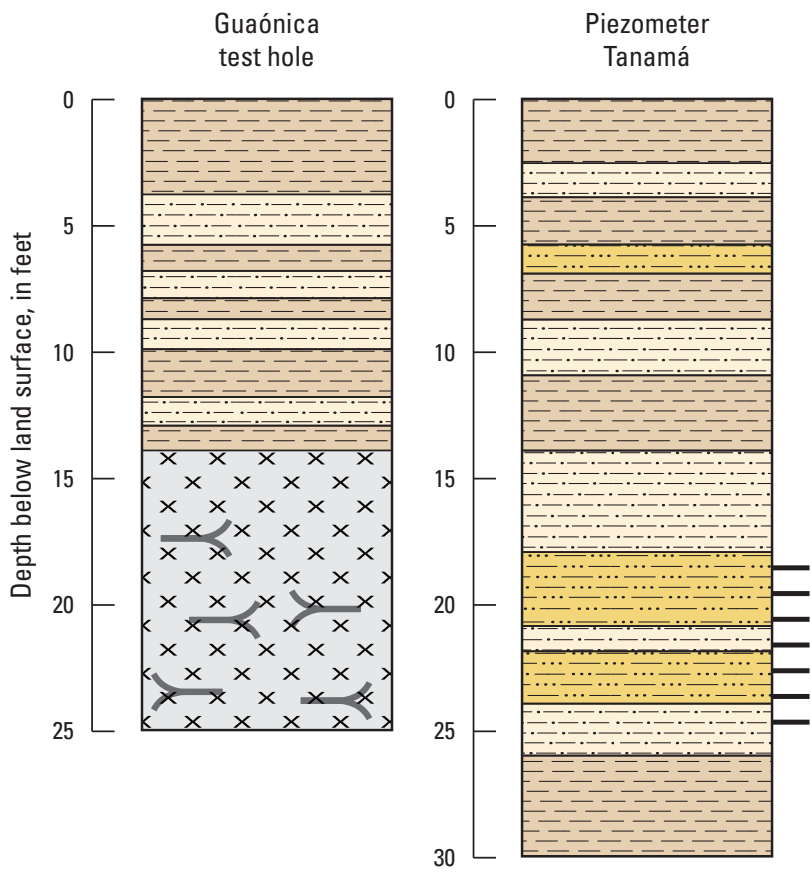

EXPLANATION

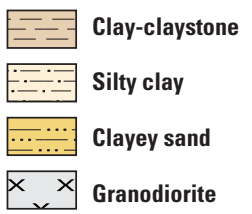

PGiS Piezometer Girau shallow

PGiD Piezometer Girau deep

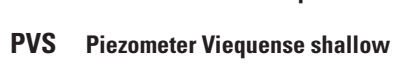

PVD Piezometer Viequense deep

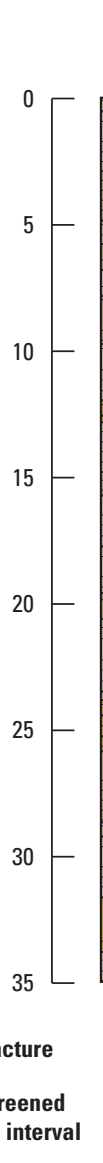

Girau farm piezometer nest

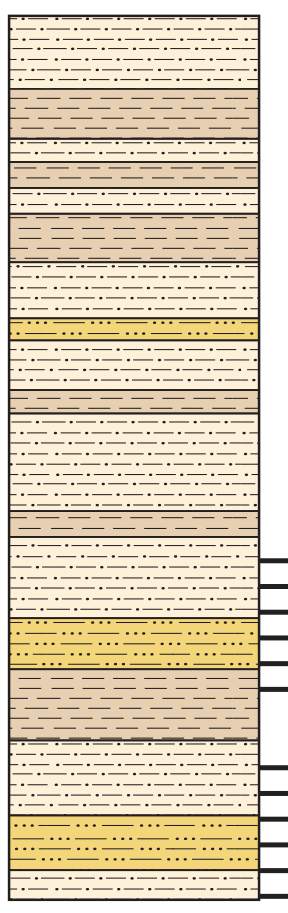

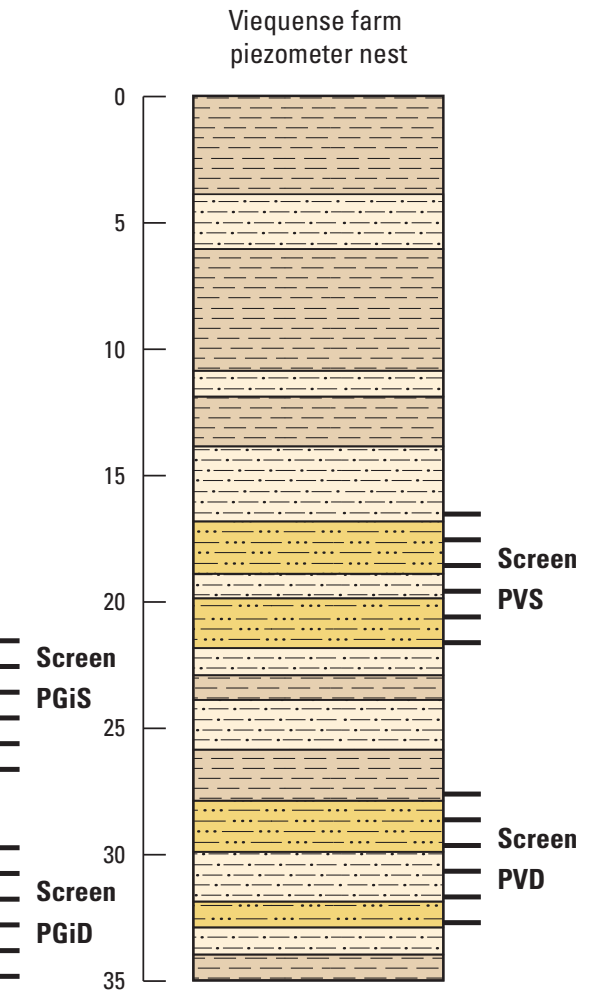

Figure 9. Lithologic logs showing main shallow lithologies and screened intervals at the test holes and piezometers in the study area. 
Table 5. Water-level data collected at selected sites in the study area.

\begin{tabular}{ccccc} 
[Altitude referenced to mean sea level] & Land surface \\
$\begin{array}{c}\text { Data collection site } \\
\text { (table 3) }\end{array}$ & $\begin{array}{c}\text { Date of } \\
\text { in feet }\end{array}$ & $\begin{array}{c}\text { Weasurement } \\
\text { (month-day-year) }\end{array}$ & $\begin{array}{c}\text { Water level below } \\
\text { land surface, } \\
\text { in feet }\end{array}$ & $\begin{array}{c}\text { Water-level } \\
\text { altitude, } \\
\text { in feet }\end{array}$ \\
\hline Viequense 1deep well (PVD) & 1,881 & $5-06-2010$ & 28.45 & $1,852.58$ \\
& & $8-18-2010$ & 23.81 & $1,857.20$ \\
Gir deep well (PGiD) & $10-07-2010$ & 22.04 & $1,858.97$ \\
& & $12-02-2010$ & 23.63 & $1,857.40$ \\
& 1,778 & $05-04-2010$ & 25 & 1,753 \\
Río Tanamá well (PRT) & $08-18-2010$ & 20.86 & $1,757.13$ \\
& & $10-07-2010$ & 12.89 & $1,765.01$ \\
& & $12-02-2010$ & 14.89 & 1,763 \\
& 1,984 & $5-10-2010$ & 20 & 1,964 \\
\hline
\end{tabular}

values of about $47 \mathrm{in}$. at the Rio Tanamá gaging station near Tanamá (50027850) and about 54 in. at the Rio Guaónica station near Utuado (50027880), the mass balance-estimated ET values were 49 and 42 in., respectively. The higher estimated ET occurred in the Rio Tanama Basin, which is relatively rich in Type II land use (sun coffee, pasture) compared to the Rio Guaónica Basin (table 4).

\section{Streamflow and Base-Flow Hydrology}

The magnitude of base flow within the two sets of paired basins varies seasonally (Rodríguez-Martínez and Santiago, 2017). Minimum base flows occur during the annual dry season, which generally extends from January to March, and maximum base flows occur during the wet season, which generally extends from August to October. During the dry season or periods of below-normal rainfall, base flow is either the primary or sole component of streamflow. Daily mean base flow ranged from 3.2 to $20.5 \mathrm{ft}^{3} / \mathrm{s}$ at the Rio Guaónica Basin, and from 4.2 to $23.0 \mathrm{ft}^{3} / \mathrm{s}$ at the Rio Tanamá Basin (fig. 10A, B). The base flows during 2010 ranged from 0.28 to $0.98 \mathrm{ft}^{3} / \mathrm{s}$ at Tributary 1 and from 0.22 to $0.58 \mathrm{ft}^{3} / \mathrm{s}$ at Tributary 2 (fig. 10C). In Tributaries 1 and 2 of Río Coabey, however, base flow was assumed to be essentially equal to measured streamflows, except during and immediately after rainfall events (during which streamflow measurements were not performed). This pattern prevails because the tributaries are in the uppermost part of the drainage basins and the amount of time during which overland runoff occurs is minimal. The normalized base flow per unit area at the Río Guaónica and Río Tanamá Basin during 2010 ranged from 1.3 to $8.1\left(\mathrm{ft}^{3} / \mathrm{s}\right) / \mathrm{mi}^{2}$ and from 1.1 to $6.1\left(\mathrm{ft}^{3} / \mathrm{s}\right) / \mathrm{mi}^{2}$, respectively. The base flow per unit area for the basins of Tributary 1 and Tributary 2 of Río Coabey during 2010 ranged from 1.0 to $3.6\left(\mathrm{ft}^{3} / \mathrm{s}\right) / \mathrm{mi}^{2}$ and from 1.5 to $3.9\left(\mathrm{ft}^{3} / \mathrm{s}\right) / \mathrm{mi}^{2}$, respectively (table 6 ).
The results indicate that the mean annual base flow per unit area is similar within the larger paired basins of Río Tanamá $\left(2.74\left[\mathrm{ft}^{3} / \mathrm{s}\right] / \mathrm{mi}^{2}\right)$ and Río Guaónica $\left(3.15\left[\mathrm{ft}^{3} / \mathrm{s}\right] / \mathrm{mi}^{2}\right)$ (table 7). The mean annual base flow per unit area for both of these basins is about 79 percent of the mean annual streamflow. In the large paired basins, the proportion of Type I land use is much higher in Rio Guaónica Basin (81 percent) than in the Rio Tanamá Basin (59 percent), and the base flow per unit area is also higher (3.15 and $2.74\left[\mathrm{ft}^{3} / \mathrm{s}\right] / \mathrm{mi}^{2}$, respectively). In the small paired basins, the proportion of Type I land use is much higher at Tributary 1 (52 percent) than at Tributary 2 (15 percent), but in contrast to the large basins, the base flow per unit area is lower (2.22 and $2.62\left(\mathrm{ft}^{3} / \mathrm{s}\right) / \mathrm{mi}^{2}$, respectively). The absence of a consistent relation between land use and normalized base flow between the two sets of paired basins is evident in these results. Factors other than land use apparently have a substantive effect on base flow in these mountainous basins.

Base flow in the large paired basins ranged from 43 to $37 \mathrm{in} / \mathrm{yr}$ in the Rio Guaónica and Rio Tanamá Basins, respectively (table 8). This base flow corresponds to 45 and 39 percent, respectively, of the about 96 in. of annual rainfall in 2010 at Barrio Roncador. The estimated low-flow values in the two large basins (18 and $17 \mathrm{in} / \mathrm{yr}$, respectively) are comparable, indicating that the differences in land use do not have a substantive effect on the lower range of base flow. Base flow in the small paired basins of the Rio Coabey ranged from $30 \mathrm{in} / \mathrm{yr}$ in Tributary 1 to $36 \mathrm{in} / \mathrm{yr}$ in Tributary 2. This base flow corresponds to 37 and 44 percent, respectively of the about 81 in. of annual rainfall in 2010 at La Mira. The base flow was lower in the Tributary 1 basin, which has a higher proportion of Type I land use compared to Tributary 2, indicating the possibility of relatively higher ET in Type I landscapes. Low flow was not estimated in the small basins because the 95-percent exceedance could not be calculated with the limited number of discrete measurements. 

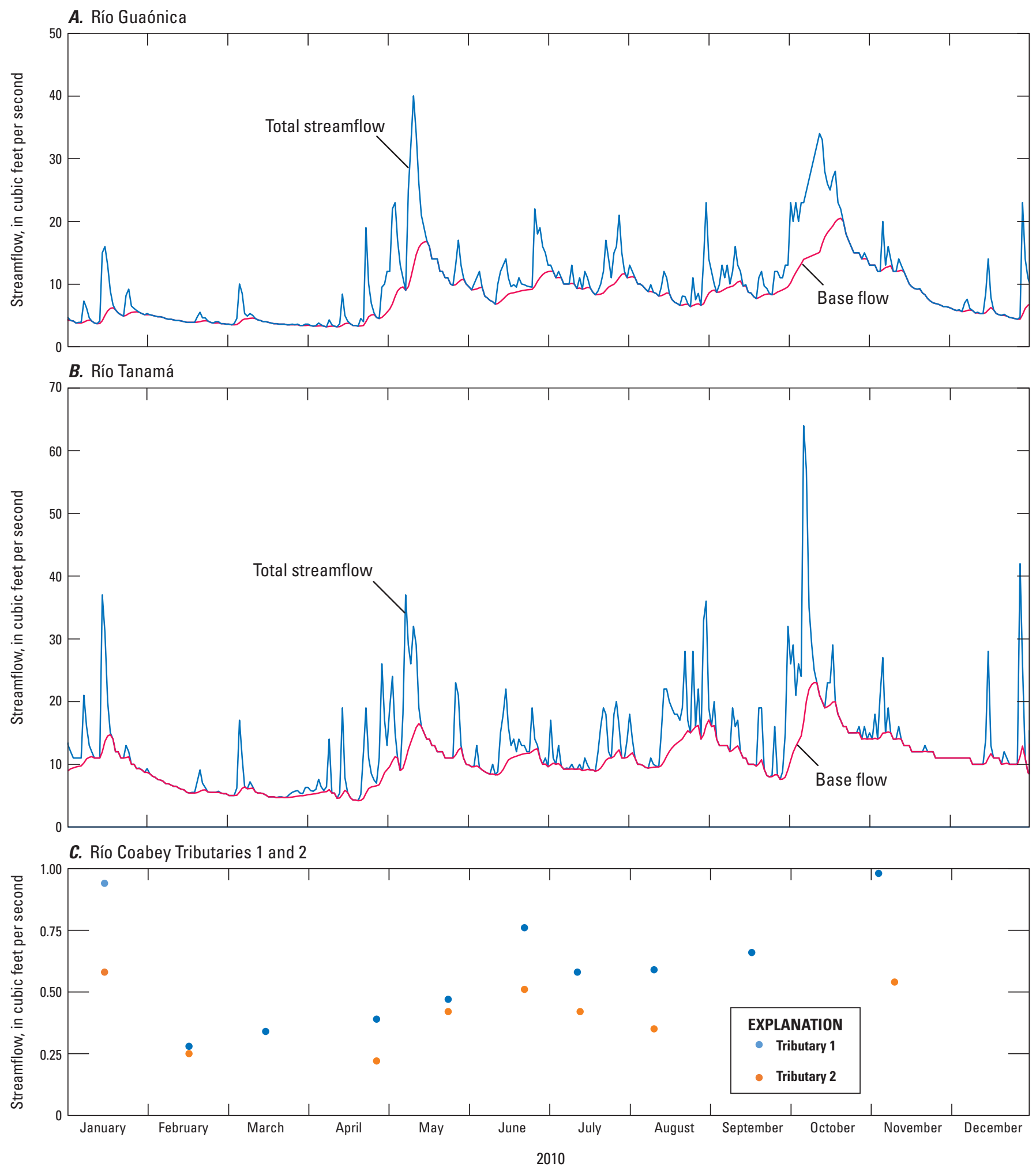

Figure 10. Base flow computed for, $A$, Rio Guaónica, $B$, Rio Tanamá, and $C$, Rio Coabey Tributaries 1 and 2. 
Table 6. Range in normalized daily base flow at the paired basins for calendar year 2010.

$\left[\left(\mathrm{ft}^{3} / \mathrm{s}\right) / \mathrm{mi}^{2}\right.$, cubic foot per second per square mile]

\begin{tabular}{lcc}
\hline Basin & $\begin{array}{c}\text { Minimum base flow, } \\
\text { in }\left(\mathbf{f t}^{\mathbf{3}} \mathbf{s} \mathbf{s}\right) / \mathbf{m i}^{\mathbf{2}}\end{array}$ & $\begin{array}{c}\text { Maximum base flow, } \\
\text { in }\left(\mathbf{f t}^{\mathbf{3}} \mathbf{/ s}\right) / \mathbf{m i}^{\mathbf{2}}\end{array}$ \\
\hline Guaónica & 1.3 & 8.1 \\
Tanamá & 1.1 & 6.1 \\
Tributary 1 & 1.0 & 3.6 \\
Tributary 2 & 1.5 & 3.9 \\
\hline
\end{tabular}

Table 7. Mean annual streamflow and base flow at the two paired basins in calendar year 2010.

$\left[\mathrm{mi}^{2}\right.$, square mile; $\mathrm{ft}^{3} / \mathrm{s}$, cubic foot per second; $\left(\mathrm{ft}^{3} / \mathrm{s}\right) / \mathrm{mi}^{2}$, cubic foot per second per square mile; na, not available]

\begin{tabular}{lcccc}
\hline $\begin{array}{c}\text { Stream } \\
\left.\text { (drainage area, } \mathbf{~ m i}^{2}\right)\end{array}$ & $\begin{array}{c}\text { Mean annual } \\
\text { streamflow } \\
\left(\mathbf{f t}^{3} / \mathbf{s}\right)\end{array}$ & $\begin{array}{c}\text { Normalized } \\
\text { mean annual } \\
\text { streamflow } \\
\left(\left[\mathbf{f t}^{3} / \mathbf{s}\right] / \mathbf{m i}^{2}\right)\end{array}$ & $\begin{array}{c}\text { Mean annual } \\
\text { base flow } \\
\left(\mathbf{f t}^{3} \mathbf{s}\right)\end{array}$ & $\begin{array}{c}\text { Normalized mean } \\
\text { annual base flow } \\
\left(\left[\mathbf{f t}^{3} / \mathbf{s}\right] / \mathbf{m i}^{2}\right)\end{array}$ \\
\hline Río Tanamá $(3.78)$ & 13.0 & 3.45 & 10.34 & 2.74 \\
Río Guaónica (2.52) & 10.1 & 4.0 & 7.93 & 3.15 \\
Tributary 1 (0.27) & na & na & 0.60 & 2.22 \\
Tributary 2 (0.15) & na & na & 0.39 & 2.62 \\
\hline
\end{tabular}

Table 8. Normalized base flow and low flow in the two paired basins during calendar year 2010 .

[in/yr, inch per year; na, not available]

\begin{tabular}{lcc}
\hline Stream basin & $\begin{array}{c}\text { Base flow } \\
\text { (in/yr) }\end{array}$ & $\begin{array}{c}\text { Low flow* } \\
\text { (in/yr) }\end{array}$ \\
\hline Río Tanamá & 37 & 17 \\
Río Guaónica & 43 & 18 \\
Tributary 1 & 30 & na \\
Tributary 2 & 36 & na \\
\hline
\end{tabular}

*The flow exceeded 95 percent of the time during the study period. 


\section{Summary and Conclusions}

During the annual dry season in Puerto Rico, base flow is the primary or only source of surface water for human consumption, for support of aquatic biota, and assimilation of organic-waste discharge. Studies by the U.S. Geological Survey during the late 1990 s and early 2000 s to assess the potential water-resources development of several municipalities indicated a direct relation exists between the magnitude of base flow and the extant mature forest cover in the highlands of the mountainous interior of Puerto Rico, where rainfall substantially exceeds evapotranspiration, generally at altitudes exceeding 1,000 feet above mean sea level. The present study was conducted by the U.S. Geological Survey, in cooperation with the Puerto Rico Department of Natural and Environmental Resources, to examine the relation between forest cover and the magnitude of base flow at two sets of paired drainage basins within the mountainous highlands of Puerto Rico.

Base-flow magnitude was compared with the areal extent of forest cover in the basins of the Río Tanamá and Río Guaónica, two tributaries of the Río Grande de Arecibo, with drainage areas of 3.78 and 2.52 square miles, respectively. The Río Tanamá Basin has more diverse land use and a smaller extent of forest cover (59 percent), than the Río Guaónica Basin (81 percent); both basins have similar geologic substrate, topographic slope, aspect, and rainfall pattern. Two smaller basins designated as Tributary 1 and Tributary 2 of the Río Coabey, which in turn is a tributary of the Río Tanamá, were examined. The basin of Tributary 1 ( 0.27 square mile) has a larger percentage of forest cover ( 52 percent) than the basin of Tributary 2 ( 0.15 square mile; 15 percent), but both have similar geologic substrate, topographic slope, aspect, and rainfall pattern. The base-flow magnitude was normalized on a unit area basis (cubic foot per second, per square mile) for comparison purposes. Data concerning the climate, geology, and hydrogeology of the two sets of paired basins also were examined.

The results indicate that, in these mountainous areas, a substantial amount of the annual rainfall (45 to 39 percent in the Rio Guaónica and Rio Tanamá, respectively) can migrate to the subsurface and later emerge as base flow in streams. The magnitude of base flow within the two sets of paired basins varies seasonally. Minimum base flows occur during the annual dry season, which generally extends from January to March, and maximum base flows occur during the wet season, which generally extends from August to October. Daily mean annual base flow ranged from 3.2 to $20.5 \mathrm{ft}^{3} / \mathrm{s}$ at the Rio Guaónica Basin, and from 4.2 to $23.0 \mathrm{ft}^{3} / \mathrm{s}$ at the Rio Tanamá Basin. The daily mean base flows during 2010 ranged from 0.28 to $0.98 \mathrm{ft}^{3} / \mathrm{s}$ at Tributary 1 and from 0.22 to $0.58 \mathrm{ft}^{3} / \mathrm{s}$ at Tributary 2 in the Rio Coabey Basin. In Tributaries 1 and 2 of Río Coabey, however, base flow was assumed to be essentially equal to measured streamflows, except during and immediately after rainfall events (when streamflow measurements during the study were not made). This pattern prevails because the tributaries are in the uppermost part of the drainage basins and the amount of time during which overland runoff occurs is minimal. The normalized daily base flow at the Río Guaónica and Río Tanamá Basin during 2010 ranged from 1.3 to $8.1\left(\mathrm{ft}^{3} / \mathrm{s}\right) / \mathrm{mi}^{2}$ and from 1.1 to $6.1\left(\mathrm{ft}^{3} / \mathrm{s}\right) / \mathrm{mi}^{2}$, respectively. The normalized daily base flow for the basins of Tributary 1 and Tributary 2 of Río Coabey during 2010 ranged from 1.0 to $3.6\left(\mathrm{ft}^{3} / \mathrm{s}\right) / \mathrm{mi}^{2}$ and from 1.5 to $3.9\left(\mathrm{ft}^{3} / \mathrm{s}\right) / \mathrm{mi}^{2}$, respectively.

The normalized mean annual base flow is similar within the larger paired basins of Río Tanamá $\left(2.74\left[\mathrm{ft}^{3} / \mathrm{s}\right] / \mathrm{mi}^{2}\right)$ and Río Guaónica $\left(3.15\left[\mathrm{ft}^{3} / \mathrm{s}\right] / \mathrm{mi}^{2}\right)$. The mean annual base flow per unit area for both of these basins is about 79 percent of the mean annual streamflow. In the large paired basins, the proportion of Type I land use is much higher in Rio Guaónica Basin (81 percent) than in the Rio Tanamá Basin (59 percent), and the base flow per unit area is also higher. In the smaller paired basins, the proportion of Type I land use is much higher at Tributary 1 (52 percent) than at Tributary 2 (15 percent), but, in contrast to the large basins, the mean annual base flow per unit area is lower (2.22 and $2.62\left(\mathrm{ft}^{3} / \mathrm{s}\right) / \mathrm{mi}^{2}$, respectively). The absence of a consistent relation between land use and normalized base flow between the two sets of paired basins is evident in these results. Factors other than land use apparently have a substantive effect on base flow in these mountainous basins.

\section{References Cited}

Bouwer, H., and Rice, R.C., 1976. A slug test method for determining hydraulic conductivity of unconfined aquifers with completely or partially penetrating wells: Water Resources Research, v. 12, no. 3, p. 423-428

Bruijnzeel, L.A., 1990, Hydrology of moist tropical forest and effects of conversion-A state of knowledge review report: Amsterdam, UNESCO International Hydrological Programme, A Publication of the Humic Tropics Programme, Faculty of Earth Sciences, Free University, 224 p.

Germer, S., Neill, C., Krusche, A.V., and Elsenbeer, H., 2010, Influence of land-use change on near surface hydrological processes - Undisturbed forest to pasture: Journal of Hydrology, v. 380, p. 473-480.

Giusti, E.V., 1978, Hydrogeology of the Karst of Puerto Rico: U.S. Geological Survey Professional Paper 1012, 68 p.

Gómez-Gómez, Fernando, Rodríguez-Martínez, Jesús, Santiago-Rivera, Luis, Oliveras-Feliciano, Mario, and Conde-Costas, Carlos, 2001, Surface-water, water-quality, and ground-water assessment of the Municipio of Caguas, Puerto Rico, 1997-1999: U.S. Geological Survey WaterResources Investigations Report 00-4280, 42 p.

Helmer, E.H., Ramos, O., del Mar Lopez, T., Quiñones, M., and Diaz, W., 2002, Mapping the forest type and land cover of Puerto Rico, a component of the Caribbean biodiversity hotspot: Caribbean Journal of Science, v. 38, no. 3-4, p. $165-183$.

Herwitz, S.R., 1986, Infiltration-excess caused by stemflow in cyclone-prone tropical rain forest: Earth Surface Processes and Landforms, v. 11, p. 401-412. 
Hornberger, G.M., Raffensperger, J.P., and Wilberg, P.L., 1998, Elements of physical hydrology: Baltimore and London, The Johns Hopkins University Press, 302 p.

Johnson, M.S., and Lehmann, J., 2006, Double-funneling of trees-Stemflow and root-induced preferential flow: Ecoscience, v. 13, no. 3, p. 324-333.

Koichiro, K., Yuri, T., and Isami, K., 2001, Generation of streamflow volume and chemistry in a mature Japanese cypress forest: Hydrological Processes, v. 15, p. 1967-1978.

Krushensky, R.D., and Curet, A.F., 1984, Geologic map of the Monte Guilarte quadrangle, Puerto Rico: U.S. Geological Survey Miscellaneous Investigations Series Map I-1556, 1 sheet.

Lacey, C.G., and Grayson, R.B., 1998, Relating base flow to catchment properties in south-eastern Australia: Journal of Hydrology, v. 204, p. 231-250.

Lapham, W.W., Wilde, F.D., and Koterba, M.T., 1997, Guidelines and standard procedures for studies of ground-water quality - Selection and installation of wells, and supporting documentation: U.S. Geological Survey Water-Resources Investigations Report 96-4233, $110 \mathrm{p}$.

Levia, D.F., and Frost, E.E., 2003, A review and evaluation of streamflow literature in the hydrologic and biogeochemical cycles of forested and agricultural ecosystems: Journal of Hydrology, v. 274, p. 1-29.

Lim, K.J., Engel, B.A., Tang, Z., Choi, J., Kim, K., Muthukrishnan, S., and Tripathy, D., 2005, Web GIS-based hydrograph analysis tool, WHAT: Journal of the American Water Resources Association, v. 41, no. 6, p. 1407-1416.

Mainuri, Z.G., and Owino, J.O., 2013, Effects of land use and management on aggregate stability and hydraulic conductivity of soils within River Njoro Watershed in Kenya: International Soil and Water Conservation Research, v. 1, no. 2, p. 80-87.

Manfroi, O.J., Koichiro, K., Nobuaki, T., Masakazu, S., Nakagawa, M., Nakashizuka, T., and Chong, L., 2004, The streamflow of trees in a Bornean lowland tropical forest: Hydrological Processes, v. 18, no. 13, p. 2455-2474.

Mattson, P.H., 1968, Geologic map of the Adjuntas quadrangle, Puerto Rico: U.S. Geological Survey Miscellaneous Investigations Map I-519, scale 1:20,000.

National Weather Service, n.d., National Weather Service Weather Forecast office: National Weather Service Web site, accessed September 2011, at http://water.weather.gov/precip.

Nelson, A.E., 1967, Geologic map of the Utuado quadrangle, Puerto Rico: U.S. Geological Survey Miscellaneous Investigations Map I-480, scale 1:20,000.

Nelson, A.E., and Tobisch, O.T., 1968, Geologic map of the Bayaney quadrangle, Puerto Rico: U.S. Geological Survey Miscellaneous Investigations Map I-525, scale 1:20,000.
Ramos-Ginés, Orlando, 1997, Water balance and quantification of total phosphorous and total nitrogen loads entering and leaving the Lago de Cidra, central Puerto Rico: U.S. Geological Survey Water-Resources Investigation Report 96-4222, 28 p.

Robinson, M., Cognard-Plancq, A.L., Cosandey, C., David, J., Durand, P., Führer, H.W., Hall, R., Hendriques, M.O., Marc, V., McCarthy, R., Mcdonnell, M., Martin, C., Nisbet, T., Dea, P.O., Rodgers, M., and Zollner, A., 2003, Studies of the impacts of forests on peak flows and base flowsA European perspective: Elsevier, Forest Ecology and Management, v. 186, p. 85-97.

Rodríguez-Martínez, Jesús, Gómez-Gómez, Fernando, Santiago-Rivera, Luis, and Oliveras-Feliciano, M.L., 2001, Surface-water, water-quality, and ground-water assessment of the Municipio of Comerío, Puerto Rico, 1997-99: U.S. Geological Survey Water-Resources Investigations Report 01-4083, 41 p.

Rodríguez-Martínez, Jesús, Gómez-Gómez, Fernando, Santiago-Rivera, Luis, and Oliveras-Feliciano, M.L., 2002, Surface-water, water-quality, and ground-water assessment of the Municipio of Carolina, Puerto Rico, 1997-99: U.S. Geological Survey Water-Resources Investigations Report 01-4267, 45 p.

Rodríguez-Martínez, Jesús, Santiago-Rivera, Luis, GuzmánRíos, Senén, Gómez-Gómez, Fernando, and Oliveras-Feliciano, M.L., 2003, Surface-water, water-quality, and groundwater assessment of the Municipio of Mayaguez, Puerto Rico, 1999-2002: U.S. Geological Survey Water-Resources Investigations Report 03-4317, 68 p.

Rodríguez-Martínez, Jesús, Santiago-Rivera, Luis, Rodríguez, J.M., and Gómez-Gómez, Fernando, 2005, Surface-water, water-quality, and ground-water assessment of the Municipio of Ponce, Puerto Rico, 2002-2004: U.S. Geological Survey Scientific Investigations Report 2005-5243, 107 p.

Rodríguez-Martínez, Jesús, and Santiago, Marilyn, 2017, Hydrologic data for the effects of forest cover on base flow of streams in the mountainous interior of Puerto Rico: U.S. Geological Survey data release, http://dx.doi.org/10.5066/ F7N58JG5.

Taniguchi, M., Tsujimura, M., and Tanaka, T., 1996, Significance of streamflow in groundwater recharge-Evaluation of the streamflow contribution using a mass balance approach: Hydrological Processes, v. 10, no. 1, p. 71-80.

U.S. Department of Agriculture Natural Resources Conservation Service, n.d., Web soil survey: U.S. Department of Agriculture Web site accessed November, 4, 2015, at http:// websoilsurvey.sc.egov.usda.gov/App/WebSoilSurvey.aspx.

Wu, Wei, Hall, C.A.S., Scatena, F.N., and Quackenbush, L.J., 2006, Spatial modeling of evapotranspiration in the Luquillo experimental forest of Puerto Rico using remotely-sensed data: Journal of Hydrology, v. 328, nos. 3-4, p. 733-752. 

Prepared by the Lafayette Publishing Service Center

For more information about this publication, contact: Director

U.S. Geological Survey

Caribbean-Florida Water Science Center

4446 Pet Lane, Suite 108

Lutz, FL 33559

(813) 498-5000

or visit our Web site at http://pr.water.usgs.gov/ 


\section{趈}

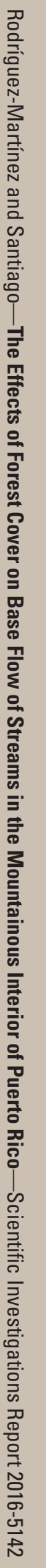

